\title{
ADMINISTRATIVE COSTS IN PUBLIC AND PRIVATE RETIREMENT SYSTEMS
}

Olivia S. Mitchell

Working Paper 5734

\section{NATIONAL BUREAU OF ECONOMIC RESEARCH 1050 Massachusetts Avenue Cambridge, MA 02138 August 1996}

Presented at the NBER Conference on Social Security Privatization, August 1996. Useful comments were provided by Jonathan Dickson, Robert Luciani, Phillip Lussier, Dennis Mahoney, Jerry Rosenbloom, and William Shipman, though none of these persons is responsible for errors or omissions. Opinions are solely those of the author and not of the institutions with whom she is affiliated. This paper is part of NBER's research program in Aging. Any opinions expressed are those of the author and not those of the National Bureau of Economic Research.

(C) 1996 by Olivia S. Mitchell. All rights reserved. Short sections of text, not to exceed two paragraphs, may be quoted without explicit permission provided that full credit, including $\mathbb{C}$ notice, is given to the source. 


\title{
ADMINISTRATIVE COSTS IN PUBLIC AND PRIVATE RETIREMENT SYSTEMS
}

\begin{abstract}
This paper collects and analyzes available information on administrative costs associated with public and private retirement systems. We explore expenses of the US social security system and compare these with data from national systems in other countries. We find that administration costs of publicly-run social security systems vary a great deal across countries and institutional settings. A key factor influencing public old-age program costs is the system's scale: plans with more assets and more participants are less expensive. We also investigate expenses reported by US pension plans and mutual funds, programs seen by many as alternative mechanisms for managing retirement saving. Based on an analysis of costs associated with retirement savings plans managed by financial institutions, we conclude that privately managed old-age retirement programs would be somewhat more costly to operate than current publicly-managed programs, depending on the program's specific design. Nevertheless these costs would be accompanied by new services for participants.
\end{abstract}

\section{Olivia S. Mitchell}

Department of Insurance and Risk Management

304 CPC, 3641 Locust Walk

The Wharton School

University of Pennsylvania

Philadelphia, PA 19104-6218

and NBER

mitchelo@wharton.upenn.edu 


\section{Administrative Costs in Public and Private Retirement Systems}

"[L]iterally every dollar which is unnecessarily or uneconomically expended on administration is a dollar which could otherwise go to the plan participants." (Hoexter 1984: 134)

“...[T]he question may well be raised as to whether the administrative expenses are too low, with the result that the insured persons are not receiving adequate service... [Social security] beneficiaries deserve better service and could well be willing to bear the slight additional amount needed" (Myers 1992: 16).

Looking across countries, government-managed old-age social security systems differ widely in the level of benefits they provide, their methods of financing, and their overall extent of redistributiveness. Despite these differences, a feature common to most of these old-age income programs is that they are heading toward insolvency. As a result, there is increasing interest in and support for moving toward a mostly-private retirement system, one which relies at least in part on investing retirement assets in private capital markets. ${ }^{1}$

This paper addresses a possible concern arising from a move toward a privatized retirement system, namely whether administrative costs in a privately managed system would be expected to be higher or lower than those found in national, centrally-run social security systems. The particular focus we take is that of the US social security system, asking the following questions:

-What are the administrative costs of the current US retirement system?

-Does the US spend too much on administering its old-age social security system?

-What are administrative costs of prominent alternatives to social security systems?

-Would a privately-managed retirement system cost more or less than the current old-age income system?

We analyze available evidence on costs associated with the US and other national social security systems, and compare them to expenses reported by various other institutions that might be seen as alternative means to supply retirement protection.

To preview the conclusions, we find that administrative costs of publicly-run social security systems vary greatly across countries and institutional settings. Some are less expensive to manage than others, and it is clear that scale matters: larger publicly-managed old-age programs cost less than do smaller public plans. It is also clear that quality varies across programs: some public 
systems have low expenses, but deliver few and/or poor quality services. While public system administrative costs could in some cases be reduced, cutting expenses cannot save an insolvent plan, and cost pressure could lessen service quality. We also examine the possibility of replacing a publicly managed retirement system with privately-managed alternatives in the United States, and conclude that a privately managed old-age retirement saving program would probably be more costly than the current publicly-managed social security program. Nevertheless, a privately managed system is likely to offer better and more diverse services in exchange for these higher costs, including the opportunity to self-direct pension asset investments, the possibility of investing in higher-return assets, the likelihood of more frequent reporting to participants, and possibly greater satisfaction with the system as a whole.

\section{An Overview of Government-Run Social Security System Administrative Costs}

It is useful to begin by recalling the objectives of a national social security system before hoping to understand whether the costs associated with managing one can be altered or reduced. Looking across countries, it is clear that two (at times competing) objectives are common to most countries' programs: providing earnings replacement for retirees, and providing welfare support for the elderly indigent. In this section we first review available data on publicly-run, governmentally managed social security systems from developed and developing countries, and then we turn to a more detailed look at the US old-age retirement income system. ${ }^{2}$ Finally, we offer an evaluation of the factors that influence social security administration costs in a multivariate framework.

\section{A. International Perspectives on Social Security Costs}

Social security systems around the world approach the twin goals of welfare and earnings insurance in numerous ways, and with weights that differ across countries. For instance, in the United States, the social security program concentrates mainly on old-age, survivor, and disability benefits, while in Europe, medical and unemployment insurance programs are also included under the social security umbrella. ${ }^{3}$ The form of the benefit varies a great deal across countries too; some follow a defined benefit formula, wherein the benefit payment is linked to years of service and 
earned income, while others follow a defined contribution approach, tying payments to assets accumulated in an investment account.

Because our focus is on the expenses associated with running a retirement system, it is useful to define social security administrative expenses as the costs of providing these retirement benefits. That is, we focus not on the tax and/or investment revenue used to pay benefits, but rather on the expenses incurred in collecting the funds, managing the records, investing the money, determining eligibility, and paying out benefits.

An economic measure of this concept would include the full resource costs of producing these services, which is not necessarily the charges that government agencies report. A discrepancy sometimes occurs because government services are often not valued at their economic resource cost -- particularly when public agencies do not purchase their inputs in a competitive market.

As an example, many governmentally-managed social security systems use public buildings and land. Reported social security administration costs under such a system will not reflect economic scarcity values. Nor will reported public sector provision costs be an accurate estimate of the likely costs private sector counterparts would charge in performing the same services. Similarly, government contracts to install computer systems are awarded on a non-competitive basis in many countries, and in other cases the public pension agency may obtain its mail and telephone services at a subsidized rate. Depreciation and fringe benefits often do not appear on a government agency's budget, and costs of collecting the payroll tax are often shouldered by the central tax authority.

For all these reasons, publicly-managed old-age programs would be expected to appear less expensive than they actually are, relative to privately managed plans. Conversely, when services are contracted through private firms, administrative costs will probably appear higher than in public plans because market prices for inputs will have to be paid. As a result, the resulting public/private cost differential may be more apparent than real. ${ }^{4}$

Keeping these caveats in mind, we next review reported social security administration costs around the world from almost fifty developed and developing countries. ${ }^{5}$ Table 1 reveals that 
countries in the Organization for Economic Cooperation and Development (OECD) spent an order of magnitude less on social security costs at the end of the $1980^{\circ} \mathrm{s} \cdots 3$ percent of their annual system budgets -- as compared to the developing nations of the Latin American and Caribbean region (LAC), where administrative costs ran 28 percent of annual expenditures.

One of the least costly programs on the list in Table 1 is the US old-age program, whose reported administration costs stood at less than one percent in $1990(0.7 \%)$ of old-age benefit expenditures after falling by a third during the 1980's. By contrast, the LAC countries with the lowest reported administration costs as a fraction of benefit expenditures included Argentina, with reported administration costs for its public plan at $2.3 \%$ of benefit expenditures, Costa Rica with $4.8 \%$ of benefit expenditures devoted to administration costs under the old-age and disability insurance, and Chile's public plan with an $8 \%$ expense rate overall (Sunden and Mitchell 1993).

Part of the explanation for the marked differences in social security administrative costs across countries is that program objectives vary internationally, in terms of the particular mix of social assistance (benefits tied to need) versus insurance (benefit tied to contributions), the degree to which the programs are government-run versus privately-managed, and even the types of payments offered, including cash and in-kind transfers to the elderly, to survivors and the disabled, the sick, new mothers, the unemployed, and so forth. For example, in both Argentina and Chile the range of government programs is wide and includes old-age, survivor and disability benefits, cash sickness and maternity benefits, medical care and work injury coverage, an unemployment insurance system, and a family allowance plan. In Costa Rica, by contrast, unemployment and family allowance plans are not included in the social security system design. For this reason, crossnational data on administrative costs are somewhat treacherous to interpret. ${ }^{6}$

A related issue is how one should handle measurement problems that arise when assessing social security costs. Ideally, the administration costs would be normalized by a direct measure of the service being provided .- namely, social security administration. Unfortunately there is no simple measure of this multidimensional service. Normalizing by total benefit expenditures, as in 
Table 1, tends to make costs look lower in more generous systems, and also in mature systems with many beneficiaries versus contributors. Conversely, costs appear lower in systems paying high benefit levels, when one normalizes program expenditures by beneficiaries. Normalizing by assets is meaningless when the publicly managed plan has few assets (as in pay-as-you-go systems), though this is the statistic of choice often given by private pension plans and mutual funds. Normalizing program expenditures by per capita income tend to make richer countries with more generous programs look more cost-effective. Clearly there is no perfect, nor universally accepted, normalization method to use in reporting retirement system costs.

At least one useful approximation to a measure of social security administration services is the number of clients a system serves. In other words, one could sum contributors and beneficiaries, ideally appropriately weighted to reflect the relative contribution of each client type to the administrative service demands placed on the social security agency. Lacking a simple, defensible method of assigning weights to client types, the common practice is to simply assign equal weights.

The impact of using differential cost measures across social security administering agencies is not trivial. Table 2 offers data on administrative retirement system costs in Chile, Costa Rica, Argentina, and the United States normalized by financial flows (either contribution or benefit payments). Data on four public plans were developed by Reid and Mitchell (1995), namely Chile's public sector INP system, Costa Rica's public CCSS system, Argentina's publicly-run ANSES system, and the US OASI system. Across these four public systems, administrative costs range from about 1 to $7 \%$ of benefit payments, with the lowest being for the U.S. OASI program. ${ }^{7}$ In addition, data are provided on Chile's private sector pension agencies, known as the AFP funds. These have been criticized as having high administrative costs, and certainly Table 2 indicates that they are the most costly of those shown, with 1993 administration costs equaling $17 \%$ of contributions. However it should be noted that these AFP costs have fallen steadily from a high of $25-30 \%$ of contributions at the system's inception in the early $1980{ }^{\circ}{ }^{8}$ 
To show how different normalization methods change perceptions of system expenses, Table 3 offers other variants. During the early 1990's, for example, expenses under Chile's privately-managed AFP program were roughly equivalent to those incurred by that country's public social security system (INP) on an active contributor basis -- around US $\$ 50$ per year. The figures would be even lower if one used total rather than active contributors, since there are many inactive accounts under the Chilean AFP system. On a total contributor basis, Chile's privately managed pension plan administrative costs stood at between US $\$ 23$ and $\$ 45$, only twothirds the level of Chile's public INP per-member costs (US\$1992). ${ }^{9}$ Clearly, privately managed retirement systems are not necessarily more expensive than their public sector counterparts.

Another interesting finding from Table 3 concerns the wide range of public system costs. At the low end of the range are US retirement system costs at \$12-\$14 per covered worker per year, and Costa Rica's system reported expenses are less than $\$ 10 .{ }^{10}$ At the upper end among the cases studied is the Argentinean public system, where annual per member costs total about $\$ 70(\$ 1992) .^{11}$ In any event, the Chilean public as well as private system figures appear to be about midrange in absolute dollars, and certainly not outliers in terms of available data. ${ }^{12}$

Some lessons may be drawn from the discussion thus far. First, data problems limit comparisons that can be made across systems, and no cost normalization is ideal for all purposes. When comparing costs across countries, it is likely that normalization by the number of participants comes closest to capturing trends in the levels of administrative expenses, though it cannot account for differences in the services provided .- a flaw shared by all the typical normalization procedures. Second, it would be useful to have service-specific cost-accounting, identifying the specific functions performed by a social security system, as well as the costs incurred in undertaking them.

\section{B. A Closer Look at US Social Security System Functions and Administrative Expenses}

The US social security system is a large and complex institution. Its four main programs include the Old Age (OA) retirement program, the Disability Insurance (DI) program, the Hospital Insurance (HI) program, and the Supplemental Medical Insurance (SMI) program (SSA 1995). 
Most proposals to privatize the retirement portion of the social security system have focused almost exclusively on the OASI program, and hence the discussion here will be mainly concerned with costs of administering that program. In contrast, the Medicare and disability components will not concern us further here except when data limitations require it.

Turning to Table 4, it is useful to gain a working familiarity with the size and scope of what is generally known as the retirement component of the social security system in the US. The OASDI program is a mandatory, virtually universal program, collecting tax revenues in 1994 from some 139 million workers annually, and paying benefits to 37 million retired plus 6 million disabled persons each year. OASDI system revenues in 1994 totaled $\$ 380 \mathrm{~B}$, or about $12 \%$ of covered earnings ( $\$ 2,700$ in contributions and interest per covered worker per year in 1994). OASDI system benefits came to $\$ 317 \mathrm{~B}$ in 1994 , paying an annual retired worker benefit averaging $\$ 8,400$. - approximately $35 \%$ of covered payroll .- and a disabled worker benefit of about $\$ 7,900$. Because the nation's social security system is mostly a pay-as-you-go account, the difference between system revenues and annual outlays is quite narrow. The excess revenue has been deposited into so-called trust funds projected to grow and then be depleted as the baby boom cohort ages. In 1994 the OASI Trust Fund amounted to only about $125 \%$ of one year's annual outlays or $\$ 2,270$ on a perparticipant basis. Thus the OASI Trust Fund could not guarantee a robust flow of retirement income if it were to be allocated among participants covered by the system today, contrary to some popular opinion.

In approaching the question of how expensive the current social security system is to administer, Table 4 shows that costs totaled $\$ 1.6 \mathrm{~B}$ in 1994 . This may be broken down to an annual $\$ 12$ per covered worker (or $\$ 9$ per participant including retirees). As a fraction of benefits paid, these administrative costs equaled $0.6 \%$ of benefits paid, or $0.4 \%$ of contributions. Computed administrative costs as a fraction of system assets would amount to $0.39 \%$, or 39 basis points; though this computation is the usual one reported for mutual funds, it is meaningless to report figures this way since the system is mostly unfunded. ${ }^{13}$ 
One fact to point out regarding social security administrative costs is that they have apparently fallen over time quite substantially. This pattern is partly explained by the fact that as a system grows, fixed costs can be spread over larger participant pools, and partly by the fact that benefit payouts and retiree numbers rose over time. Robert Myers (1992) traces the time path of administrative expenses since the social security program's inception, and concludes that costs in the early days of the program were over ten times greater than they are now. His analysis used total OASDHI costs, which during the $1940-44$ period amounted to $22 \%$ of benefits; at the beginning of the 1990's these total costs stood at just 1\% of benefits paid (Myers 1992: 16). This trend conceals across-program differences, however (Table 5). Costs for the old-age and survivors' program were halved between 1980 and 1994 , falling from $1.07 \%$ of benefits paid to $0.59 \%$. In contrast, administrative expenses for the DI program rose substantially over the same period, from $2 \%$ to $2.7 \%$ of benefits. It seems fair to conclude that the retirement component of the social security system has become more cost-effective over the period, but that the disability program has not. ${ }^{14}$

A different approach to measuring costs under the US retirement system is to assess the ways in which the system allocates its administrative expenditures (Mitchell and Sunden 1993). It is probably not surprising to learn that the OASI system devotes the lion's share -- $93 \%$-- of its administration expenses to the benefit function. This benefit function entails determination of eligibility for prospective retirees, spouses, and survivor recipients, along with actual payment of benefits. Because most of the payroll tax revenue is collected by the Internal Revenue Service, a relatively small amount -- on the order of $7 \%$ of administrative expenses .- is devoted to revenue collection. In this sense, the social security system benefits from substantial externalities by piggybacking on the IRS collection mechanisms and enforcement structure. Finally, a tiny fraction of expenses .- less than one one-hundredth of a percent ... is currently allocated to the money management function. This is because the social security system's Trust Funds are by law required to be invested in special issue Treasury Bills. Clearly under current regulations, there is no need 
for a large financial management staff, and the system's costs are held down because of this condition.

\section{Determinants of Social Security Retirement System Administrative Expenses}

\section{A. Measuring Inputs and Outputs}

The question of whether social security expenses are at the "right" level (or too high or low) is a difficult question to address, since often a nation's social security system is run as a government monopoly producing outputs that are not competitively priced. As a result, it is difficult to determine whether levels of output produced, costs incurred, and services generated by the government agency are comparable to or differ from what one might anticipate if the system were operated by the private sector.

As an example, the US social security retirement program currently provides benefits which are in part earnings insurance and in part redistributive welfare payments. It is debatable whether a private market could, and would, substitute for a mandatory system with an equally strong redistributive bent, particularly if participation were voluntary (Mitchell and Zeldes 1996). If one thought that private producers could replicate the social insurance program, then private sector costs could be used to compare with government costs, in order to assess whether the government program was paying an appropriate level of administrative expenses. On the other hand, if no private group could replicate the government program, it might be impossible to ascertain whether current levels of administrative costs are equal to those that would prevail in a competitive market.

In addition, of course, social security system expenses should properly be assessed in the context of a model which specifies production inputs, constraints, and the available technology with which these can be combined to produce desired outputs. In practice, it is difficult to develop such a model using real-world data, since the system produces many outputs using a range of inputs, all of which are difficult to measure empirically.

To illustrate this point it is helpful to turn to some aggregate output data on the US retirement system. Annually some 43 million recipients receive OASDI benefit checks, and about 
4.8 million new cases are filed each year (SSA, 1995: T 2.F). The SSA also collects contributions for 139 million workers and tracks earnings records of more than 200 million people over time.

These aggregate performance measures aside, it is far more difficult to determine whether the system is providing optimal levels of service for the costs incurred. In particular, the retirement system portion of the Social Security Administration (SSA) has several different responsibilities, including issuing all workers (and most recently, children) social security numbers, maintaining earnings records, and determining eligibility and paying benefits in a timely manner. The agency has set itself internal standards, which it has been meeting to a greater or lesser degree. For example, as Table 6 notes, $98 \%$ of applicants filing for Social Security numbers receive them within 24 hours and obtain their cards within 5 days; there appears to be little error in this process. This is a massive task, inasmuch as the SSA issued 17 million new numbers per year in the early 1990 's (personal interviews with SSA). (That the system has upgraded service from the early $1980^{\circ} \mathrm{s}$ is evident from the fact that a decade ago, obtaining a social security number took six weeks; Sunden and Mitchell 1994).

Nevertheless the system seems to be slow in tracking earnings and contributions. Under current law, employers furnish reports of wage earnings to the SSA (the self employed report pay via their income tax reports). Annually on the order of 227 million earnings reports are received. Of late there has been some delay in the recording of earnings within the Agency's own recommended time line, such that only $70 \%$ of earnings were posted within 6 months of the tax year end in 1991 (though accuracy rates were $99.2 \%$ as per Sunden and Mitchell 1993). This performance is within the Agency's standards, and is certainly a vast improvement since the early 1980's when updating of earnings records took two to three years (Doggette 1988). Nevertheless, it might be suspected that delays in posting earnings would be quite problematic if the system were to move toward an individual-account type program. Indeed, when lags of 90 days were recently detected for privately sponsored 401(k) accounts, the US Department of Labor deemed this period unusually and unacceptably long (Limbacher 1995). 
Since benefit payments are the major activity of the SSA, it is here that performance data are most critical. One performance statistic (see Table 6) indicates that about $95 \%$ of all initial benefit payments are correctly determined each year. Overall, new claims are around 7 million per year (counting all OASDHI applicants), and meeting this workload is a substantial task. A different way the SSA judges its performance is by its new claims accuracy rate, which stood at $99.8 \%$ for oldage benefits, and 94.2\% for DI benefits (in 1993; SSA 1995: T 2.F7). A further performance standard is the computed "accuracy of lifetime benefits per award", which is reported close to $100 \%$ for some time. Finally, the Agency monitors whether benefits are received on time. On average, it takes 17 days between the time a retiree files for benefits and the first payment is received, a figure slightly higher than the performance target of 15 days. The Agency also reports that it makes $99.9 \%$ of retirement benefit payments on the scheduled delivery dates, a statistic that is certainly consistent with reliable service.

In providing these services, the Agency is aware of and seeks to reduce system fraud. As in all programs, some level of investigation is required to determine whether new applicants are in fact eligible for benefits, and whether current beneficiaries should continue to receive payments. Common forms of deception include failure to notify the Agency when recipients change eligibility status (due to marriage or death, for instance); also some participants have more than one social security number, potentially enabling them to receive multiple benefit checks. As the SSA has upgraded its computer files and systems in the last decade, greater cross-checks have become feasible. In addition, in recent years the SSA has required beneficiaries to recertify their eligibility periodically and actively pursues allegations of fraud through the office of the Inspector General (Sunden and Mitchell 1994).

Whether the optimal level of output (including service and fraud control) is being expended by the SSA is difficult to be determined given available data. What we do know is that the Agency has faced substantial cutbacks in its workforce over the last decade, such that it now employs some 64 thousand full-time employees, or 0.37 employees per 1,000 active participants, down from 0.68 workers per 1,000 insured in 1980 (Table 4 and Sunden and Mitchell 1994). Downsizing was made 
possible by the introduction of an new computer system that helped reduce reported administrative costs by about one-third over the last couple of decades (Doggette 1988). Computerization also permitted better cost accounting for each separate Agency function, including tracking of personnel salary and benefits (accounting for approximately 60\% of SSA expenses). One potentially troublesome area identified by the US General Accounting Office is the fact that it is not always possible to detect poorly performing SSA employees; hence Federal government employees tenure is not readily rescinded in such cases (USGAO 1989).

How do US system performance levels compare to those of other nations? ${ }^{15}$ With regard to collecting tax contributions, for instance, the Chilean private system reports an error rate of $0.8-1 \%$ in posting contributions to individual accounts, similar to the US SSA's error rate of $0.8 \%$ in posting contributors' Summary Earnings Record. ${ }^{16}$ The Chilean private pension system appears to do better updating accounts, reporting only $6 \%$ delayed accounts within a one-month window (in the US there is a $30 \%$ incidence of non-updated accounts within 6 months of the close of a tax year). Another issue has to do with system evasion, an increasingly serious problem around the world. Argentina reports that as many as half of all eligible contributors do not pay into the system, and in Uruguay the figure is estimated at 44\% (Reid and Mitchell 1995). Having a computerized database of covered earnings greatly facilitates this supervisory task, as in the United States and many other developed nations. It is likely that a system will be more efficient when the revenue collection and record-keeping functions are handled by a single agency, and thus when Mexico developed its new individual account retirement system, it opted for centralized computer technology to track taxed paid and benefits delivered.

Performance can also be compared with regard to the effectiveness of delivering retiree benefits. This complex of tasks is handled rather inexpensively by the US social security system, since initial payments are in error only $5 \%$ of the time, and a mere 17 days are required to process an old age pension claim (it takes 90 days to process a disability claim). In contrast, the Chilean privatized pension system reports a $27 \%$ error rate in benefit determinations, and processing of normal retirement pension determinations requires 17 days, while for early retirement and survival 
pensions it takes 65 and 74 days respectively (and 146 days for a disability pension application). Public plans in other countries fare poorly on this criterion as well: in Costa Rica, 20-50\% of old-age pension determinations are appealed annually, after 60-150 days to process an old age pension and 150-180 days to process an invalidity pension. The public pension system in Argentina, ANSeS, requires 60-150 days to process pension claims, and almost one third of all benefit determinations are appealed. One positive finding is the Chilean public pension (INP) system was successful in its effort to halve its determination times between 1990 and 1993, as a result of concerted effort on the part of the government and international lending agencies. In general, both privately and publiclyrun retirement systems could improve service quality to program beneficiaries (Reid and Mitchell 1995).

A third function which both public and private retirement systems bear responsibility for is the management of contributed funds. It seems reasonable to expect that assets held in a partially (or fully) funded system should be invested prudently, following accepted money management (and possibly fiduciary) practices. By law in the US, social security Trust Fund investment practices are sharply constrained, but in other countries more flexibility is evident and performance has been widely variable. Overall, it appears that private pension system managers subject to competitive market pressures often tend to generate higher real rates of return on average than do publicly managed funds. For example, the Chilean private defined contribution system reported returns of $13 \%$ and $9.2 \%$ over the $1980-85$ and $1985-90$ periods respectively (Valdes-Prieto 1994 ); this exceeded returns of $7.7 \%$ and $9.6 \%$ achieved by the U.S. SSA fund over the same periods, as well as the $7.8 \%$ return in large U.S private pension funds, and the $9.2 \%$ and $7.3 \%$ returns earned by public funds in eight industrial countries. ${ }^{17}$ Even worse, Costa Rica's and Peru's public pension funds reported negative real rates of return over the decade of the 1980 's -- as have large numbers of other public pension systems around the world (World Bank 1994).

To sum up thus far, assessing the efficiency of the US government-run social security system is problematic because it is a government monopoly, providing services for which there are no precise private market counterparts. In any event, administrative expenses for the US Social 
Security Administration's old-age retirement program are moderate in terms of international comparisons, and also have declined over time. US annual retirement system administration costs currently cost under $\$ 15$ per worker; these equal $0.42 \%$ of contributions, or $0.57 \%$ of benefits paid. As a percentage of system assets, costs sum to $0.39 \%$ or 39 basis points; this figure is not directly comparable with privately managed plans, however, since the system is only very partially funded. Also, inasmuch as social security taxes are collected by the IRS, and the SSA Trust Funds are invested in Treasuries, the majority of administrative costs are attributable to the benefit function.

Though it is debatable whether the system spends "enough" or "too much" on administrative expenses, it seems clear that determination of eligibility for old-age benefits is handled with alacrity, and payments are on time. These costs have trended down in part because fixed costs are now amortized over a larger participant pool, and also due to computerization and the subsequent downsizing of the Agency. The fact that workers' earnings take a while to be posted to their Social Security earnings file does not materially influence the system as it is structured now; however, such a delay would certainly be more troublesome in an individual-account system. The DI system appears to be experiencing relatively more administrative difficulties; costs including DI are under $\$ 20$ per worker; $0.68 \%$ of contributions; $0.93 \%$ of benefits; and $0.63 \%$ of the combined OASDI trust funds.

\section{B. Multivariate Models of Social Security Costs}

A more systematic assessment of social security costs is facilitated with a multivariate model linking production costs to output. While a cost function methodology is most familiar to those examining firms operating in a competitive market framework, it has also been applied to the study of governmental units in order to determine whether scale economies exist in the production of government services, and to ascertain which technological factors most influence measured costs. ${ }^{18}$

In the context of the social security question, analysts have used a general cost model relating system administrative costs to output levels, input prices, and indicators of program characteristics and technology, as follows: 
(1) Social Security Costs $=\mathbf{f}($ Output, Input Prices, Program Characteristics, Technology)

The idea is that social security costs, usually measured as reported administrative expenses somehow normalized, should be influenced by output (proxied by benefit measures such as system expenditures), holding constant other factors. Depending on the country and system under study, one would want to control on other factors such as input prices (for labor, land, and capital), and program characteristics varying by locale including, for instance, whether the program is means tested, whether it is centrally run or decentralized, and other related aspects of the program itself. Additionally, when one looks across systems and countries, it is clearly important to try to control for differences in technology, including the degree to which computerization has been achieved by the system, the degree to which the system relies on a modern communication and banking infrastructure, and the overall literacy (and perhaps financial literacy) rate in the population. Finally, as Valdes Prieto (1993 and 1994) has pointed out in a case study analysis of Chile, the US, Malaysia and Zambia, it is important, but extremely difficult, to control for quality differences in services provided across public pension systems.

For all of these reasons, and others relating to data limitations, only a few studies have estimated a multivariate model of social security administration costs. The few economic studies that do, adopt a simple Cobb-Douglas cost specification, relating social security administration expenses across a set of developed and developing nations to output measures (Mitchell et al. 1994a b; Palacios 1994). In this framework, both costs and output are measured in natural logs, so that the estimated coefficient $a_{1}$ in the following equation is interpreted as a measure of scale economies:

(2) Social Security Expenses $=a_{o}+a_{1}$ Output Measures $+a_{2}$ Input Prices

$+a_{3}$ Program Characteristics $+a_{4}$ Technology $+\varepsilon$

That is, if $\mathrm{a}_{1}$ proves to be less than unity, it would be concluded that larger systems would be less expensive to operate than smaller systems. One problem with this prediction is that only rarely do countries report expenses for their old-age programs separately from their other programs, and thus overall costs would be anticipated to rise when the social security system has many different social insurance program obligations. Hence the empirical models seek to control for the fact that in 
some countries the social security agency is responsible for retirement payments as well as provision of health care, unemployment insurance, maternity care, etc. It is likely that cash payments to general retirees are less costly to deliver than are means-tested and non-cash benefits like health care and food stamps.

Another hypotheses tested with this framework is that social security systems may be more costly to operate when more agencies are involved. Unlike in the United States, in some countries the federal, state, municipal, and even smaller units of government are involved in the collection of revenue and disbursal of social security benefit payments. Looking across countries, it is also important to control on the degree to which the population is integrated into a national financial system; in practice this is often done with a proxy variable measuring the fraction of the population that is rural-dwelling, which probably is inversely correlated with computerization, integration into a banking system, literacy, and so forth. Finally, it is useful to control on differential input prices across countries, though in practice obtaining good measure of this proves difficult; one approach is to include a measure of GDP per capita to capture cross-country differences in pay.

Turning to the empirical findings, Mitchell et al. (1995) use as a dependent variable Social Security administration costs expressed as a percentage of GDP (to control for exchange rate differences) and regress this against social security benefit expenditure (also standardized by GDP). ${ }^{19}$ The analysis uses cross-section data for 43 countries including all the OECD nations as well as those in the Latin American and Caribbean region. For this sample, the authors find evidence of substantial scale economies, irrespective of the other control variables included in the equation. Across the sample as a whole, a one-percent increase in output measured by benefit expenditures is found to be associated with $0.5 \%$ increase in system administration costs. Further refinements indicates that a modification of this overall conclusion are required. One is that the OECD nations have very large social security systems, and appear to face constant returns to scale; hence only the Latin/Caribbean nations in this sample face increasing returns given the small social security programs they currently support. Second, for the subset of nations able to furnish cost data on the national retirement system separately from their overall social security program, 
the evidence is consistent with constant returns to scale, rather than increasing returns. These findings are robust to the inclusion of controls for other program characteristics, and none of the other factors is consistently significant in the empirical analysis.

As far as we know, the only other multivariate study of social security costs is that of Palacios (1994; summarized in James and Palacios 1995). Here the focus is on system administrative costs for 40 nations surveyed by the International Labor Organization around the year 1986. Social security system administrative expenses are regressed on the size of the participant pool, a parameter indicating whether the system offers a universal demogrant sort of benefit versus an earnings-related benefit, and a special variable to account for unusual costs experienced under Chile's privately-managed national defined contribution system. Of most interest is the finding of scale economies once again: a one-percent increase in participants raises social security retirement system costs by only $0.6-0.9 \%$. There is also evidence that a universal, demogrant system is significantly less costly to administer than a means-tested or earnings-related program. Controls measuring the country's level of technology include energy consumption, which proves to be strongly negatively correlated with costs, suggesting more developed countries manage their systems less expensively. Finally, the "Chile effect" is positive but only marginally significant (at the 10\% level), suggesting that given the small size of the system, costs are not terribly out of line.

\section{Further Considerations Regarding Social Security System Costs}

After reviewing social security costs around the world, we find that US system administrative expenses are in the middle of the range for developed nations at $3 \%$ of total expenditures, and are on the order of ten times lower than the developing country average. The US system's per active participant costs appear to be quite low (under $\$ 15$ per worker per year) compared to many other countries. For example in Chile, annual per contributor costs totaled about $\$ 30$ under the private system, and $\$ 41$ under the public system, and in Argentina the public system expenses ran \$40-60 annually. 
Nevertheless there are important, and very difficult to answer, questions about whether the funds are well-spent, and whether output levels and output quality is as good as it could be given available funds and technology. In many countries including the US, for instance, service could be improved by cutting the delays experienced in posting earnings to the social security records. In many countries system evasion of social security taxes is an important and growing problem, as in Japan and in Chile where some $30-50 \%$ of earnings are believed to be outside the purview of the payroll tax (Watanabe 1996; Valdes Prieto 1994). Another difficulty is that plan participants are beginning to expect private market rates of return on their contributions to the social security system, despite the fact that usually most government old-age pensions are defined benefit rather than defined contribution promises. This expectation has not been met by public pensions around the world producing zero or negative real rates of return on assets over the last decade (World Bank 1994).

As a result of these issues, serious questions are now being raised about the ability of conventional government-run social security programs to produce high-quality money management, benefit delivery, and other services, in countries around the world. Therefore we turn next to examine costs of possible alternatives to a publicly managed social security agency, with the intention of comparing potential costs across sectors.

\section{Administrative Costs of Alternatives to Social Security}

One reason to assess expenses incurred in running the government-run social security system is that market alternatives might be expected to result in lower costs and/or greater services provided. Costs could be high in publicly-provided plans if, for example, if there were diseconomies of scale in production, or if private institutions could select more efficient technologies and inputs than government bodies. Also, under some scenarios, privately managed financial institutions might generate outputs more to participants' liking than did the public sector. In this sense, it is of interest to ask whether financial institutions such as mutual funds, pension funds, and/or life insurance companies, might be able to provide lower-cost but equivalent (or better) service than the government-managed program. 
To address this question we examine what is known about some of these alternative financial institutions, and offer some tentative conclusions about the findings. The specific institutions we analyze are the mutual fund industry, the pension industry, and the life insurance industry.

\section{A. Mutual Fund Industry Costs}

The US mutual fund industry has been in existence for at least five decades: recently, mutual funds have become the second largest financial intermediary after commercial banks (ICI 1995). In mid-1996, the industry held over $\$ 3$ trillion in assets.

As US mutual funds have grown in size and influence, financial market analysts have devoted substantial attention to assessing their investment performance, ranking individual funds, and exploring anomalies. ${ }^{20}$ Analysts agree that understanding mutual fund costs requires delving into two general categories of charges, namely loads and expenses. ${ }^{21}$ Loads refer to commissions levied at the time the investor purchases or sells fund shares, or may be exacted when the investor reallocates fund shares across holdings in a "fund family". For example, a fund's front-end load is computed by subtracting the price at which one may purchase a fund share (the buy price) from the price at which one may sell the fund share (the sell price); this figure divided by the buy price equals the front-end load. Commonly seen loads or commissions range from 4 to $8.5 \%$ of invested assets; no-load funds do not charge this fee. In back-loaded funds, the term generally refers to a commission associated with redeeming a fund investment, which may be a flat rate or a percent of assets. A mutual fund employing this type of load may levy a 5-6\% charge if the funds are withdrawn during the first year of the investment, with the rate declining to zero over six or seven years. Additionally, some funds charge an exchange or transaction fee when dividends are reinvested, and/or impose a fee when assets are shifted across different fund types.

These loads are reported in fund prospectuses in accordance with regulations devised by the Securities and Exchange Commission, but are typically not included in expense ratio information. Instead, expense ratios refer to the fraction of investor assets expended annually in fees and charges. Included in this tally are operating expenses due to investment advisory/management 
fees, and costs attributable to fund administration. In addition, mutual funds must report so-called "12b-1" expenses, or distribution costs that may be charged to fund assets. Under SEC rules, such fees and charges must be included in the expense ratio information reported by mutual funds. However, the fact that loads are not incorporated in expense ratio data should be kept in mind when comparing expense ratios across funds, particularly in the retail or individually purchased mutual fund arena. (No-load funds are more common in the institutional market).

Table 7 summarizes categories of fund expenses from a recent Lipper Analytical Services survey of individually-purchased, mutual funds. Expense ratios for some of the larger mutual funds in this class appear in Table 8, again for the retail market. Perhaps not surprisingly, Table 7 indicates that the "index fund" group reports the lowest expense ratios of all those represented: these funds reported average costs of $0.32 \%$ of investor assets. ${ }^{22}$ This relatively low expense ratio may be compared to several benchmarks, one being the next lowest rate in the Table, which is for money market funds. This latter group reported almost double the index fund level of costs $(0.61 \%$ of assets). Another comparison group is the all-fund average of $1.05 \%$ of investor assets reported for 1994 (Vanguard 1995: 4). These cost differentials are striking because of the fact that index funds are relatively new and hence relatively small: index funds on the Lipper list start at asset levels of $\$ 100 \mathrm{M}$, with an average account size of $\$ 21,000$, whereas there are numerous money market funds on the list with over $\$ 1 \mathrm{~B}$, and average account size is double the index fund amount $(\$ 43,000$ in 1994).

To the extent that there are scale economies, and Baumol et al. (1990) has reported that there are -. costs rise by only $0.4 \%$ to $0.9 \%$ as assets grow in the mutual fund industry -. one might expect the much larger money market portfolios to be more cost effective than index funds. However at least at this aggregate level, expense ratios for larger, more actively managed funds, are higher than those for the smaller, more passively managed set. Expense ratios reported for socalled "growth" and "global" funds are even higher, at over $1 \%$ of assets per year. A possible explanation for these higher expense ratios is that the more actively managed funds tend to provide 
different service levels and restrictions over investor behavior, as compared to the passive index funds. These include differential access to check writing privileges, limits on trades over given time periods, and other such factors.

A cost metric that appears to generate somewhat different rankings uses annual dollar expenses per account, figures appearing in the last column of Table 7. Not surprisingly, the equity index fund again comes in with the lowest costs, at $\$ 68$ per account per year. But now the peraccount costs of money market and fixed income funds are far higher, between $\$ 265-300$ annually, a result stemming from their higher expense ratios and larger average account size. Even costs for the "balanced" portfolio totaled around $\$ 140$ per year (these funds seek a mix of equity and fixed income).

One possible explanation for the relatively low index fund costs is that managers in this fund group hold broadly diversified portfolios designed to match the investment returns of the overall market; on the whole they devote relatively little time and effort to stock-picking. ${ }^{23}$ This does not directly explain the differences because commissions tend not to be reported in the administrative cost figures (rather, lower commissions from a more passive management style would be capitalized in the mutual fund's share price). Nevertheless it appears that as turnover rises, so do fund expenses: thus a positive (but not precisely measured) response of turnover on expenses is also reported by Baumol et al. (1990: 185).

This matters because higher expenses would be expected to lower net rates of return on the more actively managed funds, to the extent that markets are efficient. Evidence supportive of an inverse expense/returns relationship was offered in an analysis of US retail mutual funds, that concluded that better-than-average returns earned by high-performing mutual funds were offset by higher fund expenses (Ippolito 1989). More extensive trading and investment research did appear to generate higher returns, but also produced higher costs were associated with generating these returns. ${ }^{24}$

A far lower estimate of mutual fund expenses appears to characterize those funds serving the institutional market, targeted to large investment pools such as employer pension plans. 
Because of their considerable size, these plans would be expected to benefit from some economies of scale. Nevertheless, obtaining clearly comparable estimates of expenses in this market is difficult, since the larger mutual funds tend to tailor an institutional plan to a particular employer's specification, and each custom component can alter expenses in important ways. Two examples for which data were gathered include the Institutional Index Fund at Vanguard, that reported a 1995 expense ratio of 6 basis points for a minimum $\$ 10 \mathrm{M}$ investment (down from 7.8 bp the previous four years), and the same firm's Employee Benefits Index Trust (EBIF), that charges an initial 10 bp in expenses down to $1 \mathrm{bp}$ for funds over $\$ 200 \mathrm{M}$ (a transaction fee is also charged of $0.15 \%$ on net cash flows over $\$ 4 \mathrm{M}$ ). ${ }^{25}$ After reviewing similar figures, Dickson concluded that the marginal cost of money management would be even smaller for a large, centrally held mutual fund invested in primarily in equities:

"[T]otal fees charged by an investment adviser for managing a broad equity index ... would be considerably less than 1 basis point per year. If the money manager were allowed to earn profits through securities lending activities, investment management expenses would be bid down to zero. If securities lending were prohibited, then management fees might total $1 / 4$ to $1 / 2$ of 1 basis point per year." Dickson (1996:9)

To these money management costs must be added annual per capita recordkeeping fees for individual accounts of around \$30-35 (Dickson, 1996).

In sum, data on mutual fund administrative expenses suggest several conclusions:

-The least costly retail mutual funds report expense ratios of 20 to 30 basis points at their current level of operation. They appear to be those offering a portfolio consisting of a broad cross-section of the capital market.

- Mutual fund products aimed at the institutional market report significantly lower expenses, at under 10 basis point annually for money management fees (excluding administrative expenses, thought to be around $\$ 30-35$ per year per participant).

-Until very recently, mutual funds have perceived their mission as investment companies rather than full-service retirement plan administrators, so that their expenses may fall as they learn the new market. 26 


\section{B. Costs of Managing Pension Plans}

Employer-sponsored pension plans are an institution that some believe offer a viable and cost-effective alternative to a government social security retirement program. Like the government system, a pension plan collects contributions, manages funds, keeps records, and is in charge of disbursing benefits. Pension plans also have functions and responsibilities that differ from those of a social security system, which in the US include reporting and disclosure requirements to plan participants, the government, and shareholders (in publicly held firms); monitoring and compliance with nondiscrimination laws; and in the case of a defined benefit pension, the plan must also pay annual premiums to the Pension Benefit Guaranty Corporation (see Hustead 1996).

\section{Private Sector Pension Plan Cost Levels}

Establishing pension plan total expenses has been an interest of regulators for many decades, though it remains the case that it is much more difficult to obtain good data on investment fees and recordkeeping costs in pensions, as compared with mutual funds. The standards for reporting are less clear, and employers sponsoring a single-firm pension plan tend to underreport their pension costs, since much of the record-keeping, payroll, and benefits payment work is handled in-house and not necessarily billed to the pension plan as an expense (Hoexter 1984).

It is sometimes argued that pension costs are most reliably reported in the case of multiemployer pension plans, since these plans are run by a joint union/management board that pays expenses centrally. Early evidence supportive of this notion was offered by Hoexter (1984) who found that per-member total expenses for the multi-employer plans were over six times higher than for single employer plans. She also found substantial scale economies among these plans, such that costs grew by only 2.5 when membership rose by 100 , and costs grew by two-thirds when assets were 20 times larger (Hoexter 1984). Expense ratios stood at 1.6\% of assets for multi-employer plans with under $\$ 2.5 \mathrm{M}$, but only $0.4 \%$ for plans with assets over $\$ 50 \mathrm{M}$.

More recently, the US Department of Labor has released tabulations on private sector pension plans from Form 5500 data (USDOL 1996). Required to be collected by law, the Form includes reports on plan expenses, participants, assets, and liabilities. Here again, it must be kept 
in mind that single employer pension plan expenses will tend to be underreported, inasmuch as the sponsoring companies absorb some portion of the plan's administrative costs rather than charging them directly to the pension plan. Among multi-employer pensions, where the pension plans cover employers of several different companies, reported expenses would be expected to be higher partly because a fuller accounting of costs is ensured in the multi-employer group. On the other hand, multi-employer pension costs may be unduly high inasmuch as these plans have recently faced substantial legal expenses, incurred as they seek to obtain delinquent contributions from small employers.

Private sector pension plan total expenses are summarized in Table 9 for plan year 1992, which reports expenses for pensions with at least 100 participants. ${ }^{27}$ Single employer plans in the sample held approximately $\$ 2$ trillion in assets, versus $\$ 214$ million for the multis in 1992 . Nevertheless, because 66 million participants were in the single employer plan pool and 10 million in the multiemployer pool, net assets per participant were similar, at $\$ 27$ and $\$ 21$ thousand, respectively. Annual contributions were quite different, standing at $\$ 1,600$ in the single employer plan and around half that, $\$ 900$ that year, in the multi-employer pension system. Defined benefit pensions for both employer types held more assets than did the defined contribution plans, though contribution levels in both sectors were higher than for the DB plans, attesting to the relatively mature status of the DB plans in both cases (generally contributions decline as the workforce matures and moves into retirement).

Turning now to expenses, the data reveal that among defined benefit pensions, reported per capita total expenses were between $\$ 130$ and $\$ 150$ per participant per year (1992\$). By contrast, defined contribution plan expenses were much lower, at $\$ 34$ per year for singles and $\$ 97 /$ year for multis. The fact that they were lower is in part due to lower actuarial costs and also to the fact that DC plans do not pay premiums to the Pension Benefit Guaranty Corporation (PBGC) for pension insurance. These expenses totaled $12 \%$ of contributions for single DB plans, and $17 \%$ of contributions for multi-employer DB plans. DC plans experienced lower expense rates, but again a 
sectoral difference is evident: expenses came to $2 \%$ of contributions for single employer DC plans, and $10 \%$ for the multis. In terms of assets, expenses came to $0.65 \%$ and $0.82 \%$, respectively, for multi-employer DB and DC plans.

The data also show that both types of plans devoted a similar proportion of the overall total expense to investment advisory and management fees -- on the order of $40 \%$ of the total. Single employer defined benefit plans reported costs almost $20 \%$ lower than multi-employer plans. For DC plans, the single/multi-employer differential was even larger, with single-employer plans reporting costs about one-third those of the multi-employer plans. One reason that these costs differed so is that multi-employer plans spend more on legal fees, for reasons already explained. They also devoted more money to contract administration and salaries, as compared to single employer plans.

More systematic studies of private pension plan administrative costs have been conducted by two research teams who focused on multi-employer pension fund expenses (Caswell 1986; Mitchell and Andrews 1981). Using multivariate econometric analysis, both studies concluded that economies of scale were quite prevalent in the pension industry. The former article was limited to the construction industry; in the latter research, the analysts examined a broader range of multiemployer plans using a cost function of the form:

$$
\text { Expenses }=\text { f (Participants, Assets, \% Retired, \% Pooled) }
$$

where annual plan expenses were regressed on the number of plan members and dollars of plan assets, as well as the fraction of members retired, and the fraction of the assets held in pooled funds. Data from the late 1970s were obtained from reporting forms filed under the Employee Retirement Income Security Act of $1974 .{ }^{28}$ The results provided evidence of statistically significant scale economies in this set of defined benefit plans. Specifically, holding constant the number of plan participants, increasing the plan's asset size by one percent (holding participants constant) was predicted to increase costs by only $0.27 \%$; in other words adding to existing pension plan asset pools is relatively inexpensive. That paper also showed that, raising the number of plan participants by a percent (holding benefits payable constant) would raise pension administrative costs by $0.8 \%$, or less 
than one percent. In other words, increasing the size of the participant pool by adding new members with comparable assets would raise costs by less than proportionally

An important reason to ask about variation in pension plan costs, of course, is because such variability in costs might correlate with fund performance. A multivariate regression study relating equity management fees to five-year annualized pension fund performance found that lagged strong returns were only weakly associated with higher subsequent fees (Lakonishok et al. 1992). Nevertheless, the same study concluded that the equity portion of pension portfolios underperformed mutual funds by 50 to 100 basis points between the mid $\cdot 1960$ s and the mid-1980s, suggesting that high expenses might reduce fund performance.

\section{Costs of 401(k) Pension Plans}

Over the last decade in the US, a new breed of retirement saving vehicle has grown up, namely 401(k) pensions. These plans are often thought of as a type of defined contribution pensions, but in fact have become increasingly distinct in character from the old employer-directed defined contribution pension accounts.

In a 401(k) plan, generally the sponsoring employer will select a set of investment vehicles to which participating contributors may direct their contributions; individual plan participants often have substantial flexibility over subsequent asset allocations. For example, many funds permit participants to inquire about their account balances and alter their accruals as well as new contribution flows via a 24-hour telephone service center. In addition, many employers allow participants to take loans from their $401(\mathrm{k})$ plans, a feature which increases these plans' popularity but one that would also be expected to raise their operating expenses (Mitchell 1992). In addition, the $401(\mathrm{k})$ rubric encompasses a wide range of plan types and structures including those funded by profit sharing, those with or without employer pre-tax match amounts, and thrift plans. Finally, the fact that employers are concerned about liability for participants' investment choices, substantial funds are devoted to investor education efforts as well as periodic statements of accounts to participants. 
In contrast to the old corporate (and public sector) pension model, at the time of retirement, participants in a 401(k) plan may elect from a variety of different payout options (Mitchell 1992). One is to take the accruals in a lump sum (and perhaps roll it over into a tax-qualified Individual Retirement Account); another is to use the funds to purchase an annuity; and a third is to elect a graduated payout in accordance with Internal Revenue Service requirements. Because these and other feasible payout options are tailored to the individual retiree, one might anticipate that $401(\mathrm{k})$ administrative costs would exceed those of conventional defined contribution plans.

Evidence on the cost impact of plan flexibility is as yet preliminary. Assets in 401(k) plans total more than half a billion dollars. The ICI (1995) data indicates that 401(k) plans have on the order of $18 \mathrm{M}$ participants, with assets per participant running about $\$ 26,000$ (median $\$ 16,000$ ), and median overall contribution rates of $\$ 2286$ per year (with $35 \%$ contributed by employers). Median recordkeeping expenses reported by $401(\mathrm{k})$ plans in 1993 totaled $\$ 66$ per account per year, or $3 \%$ of annual contributions. Of course, to the extent that administrative fees are sometimes charged to the 401(k) plan sponsor, reported administrative expenses may appear unduly low (ICI 1995). Nevertheless one might anticipate that $401(\mathrm{k})$ plans would require somewhat more administration than individually purchased mutual funds, inasmuch as the tax-qualified plans permit participant involvement in the asset allocation process and also require monitoring for tax purposes. On average, $20 \%$ of the $401(\mathrm{k})$ plans permit daily reallocation of accruals or new contributions; $12 \%$ permit monthly exchanges; $40 \%$ permit quarterly adjustments, and only $20 \%$ limit changeovers to once or twice a year (p. 10). While attractive to many participants, industry experts point out that permitting more transactions in retirements raises costs. Also almost three-quarters of the plans give out quarterly statements of participants' asset allocation and performance, and most devoted substantial effort to marking their assets to market, many on an hourly basis.

Table 10 indicates average total expenses charged by 401(k) pension plans, costs generally attributable to start-up fees, annual per-person service charges, loan fees, annual reporting fees, transaction charges, and approximately $5-10$ basis points for trustee charges, presumably mostly insurance (ICI 1995). As a matter of practice, money management fees are not included in these 
tallies and must be added to obtain total expenses. The data indicate that average recordkeeping expenses range from a low of 80 basis points in the short-term bond fund, to 188 basis points in international equity funds, with the midrange for equity funds around 140-150 bp per annum. On an annual basis the average per participant cost of administering a 401(k) plan appears to be between $\$ 5-55$ annually, including nondiscrimination testing, quarterly statements, and investor information. ${ }^{29}$

One of the most difficult issues in the 401(k) field is that the 401(k) plans often offer a life annuity at retirement, so that the product provided is distinct conceptually from a simpler money accumulation plan. Figuring out what additional expense the insurance annuity adds, as distinct from the money management and record keeping costs, is not a simple matter. Some modest evidence in this direction compares expense ratios for small and midsized 401(k) plans with and without an annuity product embedded in the offering; see Table 11. (Not reported are recordkeeping and administrative fees which are similar for both plan types). Not surprisingly, it appears that administrative expense ratios are higher for $401(\mathrm{k})$ plans offering insurance annuities: the additional asset-based charge over the mutual fund investment options appears to be 6 to 32 basis points. ${ }^{30}$

\section{$\underline{\text { Public and International Pension Plan Administrative Cost Comparisons }}$}

It is useful to compare of the private pension plan costs reported thus far with a range of other plans, as a method of gaining some perspective on the range of figures. Comparing expenses of large US corporate plans with US public sector pension plans and endowment/foundation funds shows that fees paid to outside managers totaled 34 basis points (bp) among public funds, versus 45 among the larger corporate funds in 1994 [Greenwich Associates 1995a, c, d]. While the government-run plans are somewhat less expensive, there is little evidence of scale economies among this set of public plans examined: public funds with over $\$ 1 \mathrm{~B}$ in assets paid 30 bp versus 37 bp for plans with less than $\$ 100 \mathrm{M}$, whereas in the corporate sector, plans with over $\$ 1 \mathrm{~B}$ in assets 
paid 33 basis points in expenses versus those with under $\$ 100 \mathrm{M}$ in assets paying 50 bp (Greenwich Associate, 1995a: 26). Nevertheless no formal model was used in that study holding other factors constant; more will be said on this below.

As we have noted, corporate plan sponsors are not required to account for all pension expenses separately, in contrast with more complete reporting in public plans. For instance in $1994,68 \%$ of US corporate pension plans reported that the plan sponsor (typically a private employer) directly paid a portion of pension plan staff costs rather than charging the pension plan, but only $\mathbf{4 2} \%$ of public sector plan sponsors devoted staff time to pension fund activities [Greenwich Associates 1995a: 35]. The smallest public/private reporting differential found is in the area of investment management fees, where $76 \%$ of the private pension funds and $77 \%$ of public plans reported that their investment management fees were charged to the pension plan [Greenwich Associates 1995a: 35]. Overall, fewer corporate funds charge actuarial fees, pension consulting fees, and performance measurement fees to the pension fund, as compared to the public plans. In general, then, the higher fees paid by US private plans are probably still underreported.

Other datasets offer distinct comparisons between US corporate funds and Canadian and British pension plan costs. Across these three groups, the US mean (median) private pension expenditure on annual money management fees is systematically the highest, at $40 \mathrm{bp}$ (38), compared to Canadian corporate funds which pay $30 \mathrm{bp}(28)$ and UK private funds where the mean is 22 bp (18). An examination of these countries' corporate pension fund management expense distributions reveals that US plans having a distribution shifted far to the right, and the two comparator nations having far fewer funds reporting expenses greater than 50 basis points [Greenwich Associates, 1995a: 26].

Other places to seek evidence on pension expenses are in the nonprofit as well as governmental pension plans. In the former case, complete expenses are reported only to the extent that the plan is charged full cost for expenses incurred its behalf. A rather interesting case is that of the College Retirement Equity Fund (CREF), the nation's largest defined contribution pension plan covering employees in higher education and research institutes. It is a non-profit institution 
and for historical reasons, receives special treatment under ERISA law. CREF is national plan, covering people in many different institutions, and employers participating in the system tend to cover most of the payroll-based costs as part of their own benefits function. This suggests that the CREF plan would appear to have lower costs as compared to a plan where all benefits and payrollrelated costs were charged to the plan. The system is also quite responsive to individual participating employers, permitting cross-employer differences in contribution levels, rules regarding lump-sum versus annuity payouts, and asset allocation choices; these differences may drive up expenses. Additionally, CREF contributions include the value of annuity insurance, since strictly speaking participants in the contributory phase purchase a deferred variable annuity. for this reason, costs would not be expected to be reflective of nor directly relevant to those experienced by corporate pensions. In any event, it is of interest to inquire about CREF's expense structure because of its large scale, and because some have suggested that this might be a viable model if social security should be partly privatized.

CREF costs are reported in Table 12, where it will be seen that total expenses (including money management and record keeping) ranged from $0.29 \%$ of assets per annum for the money market fund to $0.42 \%$ for the growth fund (plan year ending 12/94). This narrow differential is attributable to CREF"s application of identical administration and distribution expenses ( 0.21 and $0.03 \%$ of assets, respectively) to all funds. As a result, the only source of reported cross-fund variation is due to investment advisory fees that vary from $0.05 \%$ to $0.18 \%$. Certainly these are low levels of cost, and the differentials narrow, in light of the expenses reported for other funds described above. It is possible that these lower figures, 5-18 basis points, would characterize money management fees if a large scale funded government program modeled on CREF were to replace the current, mostly unfunded, social security system.

A different pension plan outside the corporate sector is the Federal Government retirement system, known as the Federal Retirement Thrift Investment Fund. This civil service retirement plan is reasonably large, including over 2 million participants and $\$ 36 \mathrm{~B}$ in assets, and is a 
contributory defined contribution plan that may be allocated at the participant's behest into a stock fund, a bond fund, and/or a government securities fund. The 1996 annual report indicates that administrative expense ratios in this system total 9 basis points; however this figure excludes costs associated with collections of employer and employee contributions, since individual agency's or office's payroll system handles these separately. Even more striking is the low reported level of investment expenses -- computed at under one basis point. This figure is indicative of the extent of scale economies feasible in a centrally managed, large defined contribution pension plan, which restricts its investment choices to a very small set of indexes.

US state and local pension plans afford another data point on large pension plan costs, but here defined benefit systems are generally the norm. ${ }^{31}$ In a recent study of more than three hundred public employee retirement systems with assets of $\$ 791$ billion and 10.6 million active members in 1992, administrative expenditures for these public employee pension plans averaged $9 \%$ of total pension contributions; median per participant expenses were $\$ 130$ per year $(\$ 1992$; Hsin and Mitchell 1994). This is comparable to private plan costs reported above (yet private plan figures may be biased downward for reasons already noted). ${ }^{32}$

The econometric analysis recognized that public sector pensions might not operate on the economically efficient feasible frontier with minimum possible expenditures, inasmuch as public retirement systems usually are not subject to market pressures. Hence a frontier cost model was estimated using a general multi-product cost function of the form:

$$
\text { Administrative } \text { Costs }_{i}=f(\text { Output Vector, Input Prices; } \alpha)+\varepsilon_{I}
$$

where $\alpha$ is a vector of parameters, and $\varepsilon_{i}$ is an error term made up of two independent components $\left(\varepsilon_{i}=v_{i}+u_{i}\right.$ where $v_{i}$ captures random error and $\left.u_{i} \geq 0\right)$. Of particular relevance to the present work is the finding of substantial scale economies: among public sector pension plans, a $1 \%$ increase in the number of plan participants raised pension administrative expenditures by $0.74 \%$, holding assets per participant constant, and a $1 \%$ increase in assets ceteris paribus raised costs rise by less than half a percent. A more troubling finding was that some thirty percent of reported 
administrative expenditures was attributed to inefficiencies, though this figure was lower than those reported in other public sector agencies.

Having measured pension plan inefficiency gaps, the analysis then explores factors associated with measured inefficiencies. The evidence suggests that public plans were more efficient when investment services were contracted out to private money managers. It was also found that granting pension boards authority over their administrative budgets reduced administrative efficiency, particularly when administrative. budgets were picked up by the sponsoring employer (versus having the pension fund cover its own costs). In general, therefore, administrative costs of public pension plans could probably be reduced somewhat, perhaps by as much as a third, with somewhat different reporting and management structures. ${ }^{33}$ Trends in Pension Administrative Costs Over Time

Estimates of trends in pension plan administration costs over time are relatively few, but one source is a recently revised and updated report on defined benefit and defined contribution pension plans over the period 1981-1996 (Hustead 1996). Table 14 summarizes annual defined benefit costs on a per person basis (in 1996 dollars) as computed from an actuarial simulation for a hypothetical plan and real cost trends over time.

The results indicate that average per-participant costs rose rapidly for all sizes of plans and for both plan types, particularly during the latter half of the 1980 's. Whereas annual private plan expenses stood at about \$23-26 per participant in larger pensions in 1981 (1996\$), by the mid 1990's the cost has risen almost three times for the defined benefit pension plan and by almost double for the defined contribution plan. Similar percentage changes characterized small pension plans, though the levels of administrative expenses for both plans are much higher because the smaller plans could less ably capture scale economies. In 1981, small plans of both types experienced per participant costs of under $\$ 200$ per year per participant in 1981 , but by 1996 , DC costs were $\$ 287$ and DB costs higher than $\$ 600$ per participant per year. Large plans reported administrative costs of $\$ 68(\mathrm{DB})$ versus $\$ 49$ (DC) per year in 1996. (It should be noted that these administrative 
expenses exclude investment management fees, but they do include Pension Benefit Guaranty Corporate premiums for the defined benefit pension plan figures).

Several explanations have been offered for the increasing cost levels as well as the rising differential between DB and DC plans; most prominent explanations are the increasingly complex nondiscrimination rules that plan sponsors must meet, and the rising cost of insurance premiums for DB pension plans (Hustead 1996; Clark and McDermed 1990).

\section{Overview}

This investigation into pension plans of different types and in different sectors suggests several conclusions regarding pension administrative cost levels, differentials, and trends. These include:

- Large corporate pension plans reported total administrative costs of $\$ 68$ (DB) versus $\$ 49$ (DC) per year in 1996. These costs have risen steadily in real terms over time.

-Scale economies are significant for pension plans. Total administrative costs are much higher .perhaps 5-10 times as high -- on an annual per person basis, in company pension plans with 15 participants versus 10,000 participants.

- Overall pension plan expenses appear to be split approximately two-fifths to advisory and money management fees, and three-fifths to contract administration and salaries. Paying benefits in the form of an annuity adds additional costs, roughly 6-32 basis points over a mutual fund investment. - US corporate pension plans report substantially higher money management fees than do their Canadian and UK counterparts, at about 40 basis points instead of 20 to $30 \mathrm{bp}$. Corporate US pension plans also report higher outside management fees than do public US pension funds (where the latter devote about 33 basis points to outside fees).

-Public and nonprofit sector pension plan expenses tend to be lower than corporate plan costs. For example, the CREF plan covering employees in higher education and research institutes reports devoting 29 - 42 basis points to expenses, with a constant fraction devoted to recordkeeping and distribution (24 bp) across plans. The Federal Thrift Retirement plan devotes 9 basis points to 
administrative costs, and less than one basis point to money management costs. These figures should not be directly extrapolated to the private sector arena however.

\section{Administrative Expenses in the Insurance Industry}

Another line of inquiry pertains to the question of how well could insurance firms supply retirement annuities, in the event that social security benefits were scaled down substantially. In this regard, it is important to address two issues: first, how efficient are privately managed insurance firms, and second, how well does the insurance market work as a whole? Presumably the appeal of social security privatization would increase if private firms could be anticipated to fill the gap, and to do so at relatively low cost.

In terms of the life insurance business in the US, the American Council on Life Insurance (ACLI 1995: 37) reports that life insurance firms in 1994 received some $\$ 453 B$ in annual premiums and investment earnings. On a per-dollar of asset basis, expenses totaled $11 \%$ of annual income (16\% of annual contributions), and amounted to some $2.6 \%$ of the asset base of almost $\$ 2$ trillion in 1994. Some $45 \%$ of the total expense dollar is devoted to selling costs, or agents' commissions.

To date much of the insurance economic literature has explored efficiency in the propertycasualty market (e.g. Cummins and Weiss 1995). As a rule these studies estimate cost functions, and the availability of firm-level panel data has permitted the estimation of quite flexible functional specifications. A persistent problem acknowledged across all these studies is that it is difficult to measure insurance firm output and quality. Hence persistent cost differentials over time between different lines of insurance and different distribution systems for the same insurance product turn out to be quite difficult to interpret (c.f. Berger et al. 1995). Nonetheless, looking across the available literature it appears that firms in the US property/casualty insurance sector are operating inside their efficient production frontier by significant margins, suggesting room for reductions in system administrative expenses. ${ }^{34}$

In addition to the general efficiency question just raised is a serious concern regarding how seriously adverse selection and moral hazard pose important real-world obstacles to the privatization of retirement annuities. Allowing individuals to elect whether to take their retirement 
accounts as a lump sum or an annuity suggests that there are some potentially troubling weaknesses in the market for annuities. One influential study concluded that expected annual yields on individual life insurance policies were approximately 2 percentage points lower than on group policies due to adverse selection (Warshawsky 1988). Other evidence suggests that purchasing individual annuities costs approximately two-thirds more than group purchase (Diamond and Valdes Prieto 1993). These findings, along with the high and not necessarily efficient annual costs reported above, suggest that privatization of the insurance portion of the system would raise costs beyond current public provision of the old-age annuity.

\section{Relating These Findings to a Privately-managed Old-Age Retirement System}

How these findings might be relevant to a privatized social security system in the US depends on the exact institutional structure that would be implied under such a reform. One option, dubbed the "Maintain Benefits" option by members of the Social Security Advisory Council, is to simply invest a portion of the existing social security Trust Fund in equities. This approach would leave intact the current revenue collection mechanism, the Social Security Administration's record-keeping and benefit payout functions, and all else; the only change would be that the government would now invest a portion of the fund, probably in an index portfolio (Quinn and Mitchell 1996).

Whether or not purists would deem this a real step toward privatization, it is nevertheless seen by many as a viable political possibility. Supporters argue that the SSA could earn higher rates of return than on Treasury bills; detractors point to the fact that system participants may be forced to confront greater capital market risk than under the current defined benefit plan (Mitchell and Zeldes 1996). In any event, it is plausible to argue that system expenses would increase as the government took on an additional money management function, but the additional costs would probably be relatively small. If the Trust Fund were simply deposited in an indexed passively managed mutual funds, administrative expenses would rise by as little as 1 to as much as 20 basis points, with the likeliest number being at the lower end of the range. 
This figure relies on cost figures currently experienced by large, passively managed, mutual funds, it could rise if more actively managed, portfolios were chosen. Some analysts have expressed concern that political pressures would be brought to bear on a government-managed pension account worth, eventually, several hundred billion dollars. ${ }^{35}$ To the extent that this did occur, expenses would be higher and investment performance lower than the returns offered by competitive privately-managed mutual funds (Mitchell and Hsin 1995). This estimate also assumes that the government would continue to collect revenues, maintain records, and disburse benefits as now; in other words, the investment fee would be the only incremental charge over the system's current expenses.

A different approach to social security privatization is the proposal to establish a "Personal Saving Account (PSA)" approach. ${ }^{36}$ This plan would require all participants to deposit a portion of their payroll taxes into individual private pension accounts managed by regulated but private fund administrators. ${ }^{37}$ These pension managers would then invest participants' assets and pay out benefits at retirement. An important question regarding how such accounts might work in the US has to do with how much self-directed investment would be permitted in the PSAs, and how interfund competition would be regulated since the system's inception. In Chile, for instance, private pension fund asset allocation decisions have been heavily restricted. There, workers may change pension allocations only 3-4 times per year (and must hold all their funds in a single pension fund at any given time), and fund managers face extensive regulation regarding asset composition, permissible (and prohibited) commission charges, and reserves. Though early in that nation's privatization drive, administrative costs were quite high (about $23 \%$ of contributions or $14 \%$ of assets), these costs have dropped more recently (15\% and $2.3 \%$ respectively). It is of course inevitable that costs would be higher initially; the subsequent downward cost trend results partly from competition and partly from scale economies as assets have grown. Still, however, after fifteen years, the Chilean AFP pension system is relatively small by US standards, having assets of around US $\$ 25 B$ (Edwards, this volume). 
If a PSA system were mandated in the US, system administrative expenses would clearly rise, but probably not as much as the high end of the costs experienced in Chile. Inevitably, specific cost rates would depend on specific plan design details, such as what investors are permitted to do with their funds, how often they can reallocate their investment portfolio, and what restrictions on fees and other rules are instituted. An optimistic assessment would take the Federal Thrift Plan numbers, where it will be recalled that only three relatively passively managed options are permitted. In that system, administrative expense ratios in this system were 9 basis points (excluding collection costs) and money management expenses are estimated at less than 1 basis point. Obviously, fund charges could be higher if people opted for more actively managed accounts; recent research on 401(k) plans has concluded that the first cohort to have access to these plans chose fixed income and guaranteed insurance company holdings, but younger participants have chosen equity funds by substantial margins (see Table 15). The CREF plan offers many additional options, and has estimated expense figures of 30-40 basis points annually (including recordkeeping).

A PSA account system that required investors to place their contributions with mutual funds would probably experience higher administrative and record-keeping fees, and also would probably incur costs associated with providing annuities. In terms of the former expense, if individual pension accounts were offered as add-ons to existing company-sponsored 401(k) plans, administrative costs would probably be on the order of $\$ 50-60$ per year. This assumes that the plan does not require (or offer) that benefits be paid out in an annuity. If one were to additionally require that benefits be paid as an annuity, costs would probably rise by an extra $10 \%$ of contributions or $\$ 100$ per participant per year, extrapolating from multi-employer defined contribution plan costs. This figure might be lower if, as the annuity market grew, private insurance firms experienced substantial scale economies; it might be higher if substantially greater adverse selection resulted from optional annuity purchases.

\section{Conclusion}


Opponents of social security privatization argue that privately-managed systems are more costly than public systems to manage, and this is a charge that advocates must evaluate carefully. This paper contributes to the discussion by exploring a range of evidence on public and private pension system administrative expenses, as well as the determinants of retirement system administrative efficiency in the US and elsewhere.

The research shows that the administrative costs of providing old-age retirement benefit services through a public system are often difficult to measure with precision. Conceptually, a comparison of public administration costs with private plan costs requires not only assessing the expenses incurred in delivering pension services, but also controlling for the quality of services delivered. Available data fall far short of the desired measures. Nevertheless, our evidence from international sources indicates that there are wide differences in retirement system administration costs from plan to plan, and from country to country. Some of these differences are due to the level of privatization, but most appear to be attributable to particular institutional structures and management practices.

For example, the US Social Security Administration manages a very large old-age system at costs which are mid-range among developed nations, but these costs are low compared to smaller systems in smaller countries. Using several different metrics, these costs may be alternatively described as $0.7 \%$ of benefit expenditures; $0.4 \%$ of contributions; $\$ 12-14$ per covered worker per year ( $\$ 9$ per participant in 1994); or $0.39 \%$ of system assets (the latter figure is however misleading because the system is mostly unfunded). In exchange for these costs, the US social security system appears to do some things quite well. Focusing on the provision of benefits, for instance, there is reason to believe that most eligible retirees receive the benefit amounts to which they are entitled on time. On the other hand, the posting of workers' earnings to system computer files could be improved, though this delay causes no particular problem under current rules. Under current rules the US social security system bears relatively small expenses for collection of revenues, and virtually nothing for money management, since funds must by law be invested in special-issue Treasury Bills. 
These figures were compared with expenses reported by a range of other financial institutions who might be potential players in a privatized social security system. Data from both retail and institutional mutual funds were collected, along with private and nonprofit pension plans, and insurance companies. Each of these private alternatives produces a somewhat different mix of outputs and with varying types of participant tailoring and service. The data suggests adding a privately managed individual savings account to existing mutual fund or $401(\mathrm{k})$ plans would be relatively low-cost, with money management fees potentially ranging between 1 and 20 basis points (for a passively managed indexed portfolio), and administrative costs of perhaps $\$ 50$ per year. Money management costs could be substantially higher for more actively managed funds.

If a group model were taken as the likely prototype of a privatized system, such as a national TIAA-CREF-type or Federal Thrift-type plan (and the range of options were limited quite substantially), investment costs have been estimated to be on the order of a basis point or less per year. Administration costs would be potentially on the order of 20-30 basis points, judging from available evidence. In addition, one must add the costs of providing longevity insurance if annuities are to be guaranteed. ${ }^{38}$

Even if a privately managed defined contribution system would result in somewhat higher administrative costs, compared to the current pay-as-you-go system, these higher administrative expenses would have consequences that many would find appealing. These additional expenses make possible a system that handles the pension system's necessary functions with greater alacrity, while permitting workers to undertake more active asset management in their retirement portfolios. A variant of this approach has been suggested by several members of the 1994-5 US Social Security Advisory Council: under this scenario, the government would offer and manage three to four funds among which plan participants could choose. This approach would also result in higher administrative costs as compared to the current social security system, but would still permit some of the advantages of having individual accounts.

All of the privatization options considered here would be expected to cost somewhat more in administrative expenses than the current publicly-run plan in the US, but the precise level of 
administrative costs in a privatized social security system will depend crucially on the specifics of the plan proposed. Costs will rise, experts believe, if actively managed funds are permitted, if twenty-four hour call-up access were allowed, and if participants can obtain loans from the funds. Some of the variants would also entail higher collection costs, reporting expenses, and insurance annuity costs. A lower-cost system would require only a few investment options with little hands-on participant access and infrequent reporting. Offsetting these additional costs, of course, are potentially substantial economic benefits flowing from having a privately-managed system (Feldstein 1995; Kotlikoff 1996; Quinn and Mitchell 1996; Mitchell and Zeldes 1996). These benefits could include the opportunity for participants' contributions to earn a higher rate of return than that feasible under the public program, the possibility that labor supply and savings disincentives would be diminished, and a reduction in the political risk regarding future benefits. 


\section{References}

American Council on Life Insurance (ACLI), Life Insurance Fact Book, 1994. and Supplement 1995 Washington, D.C.: American Council on Life Insurance.

Arthur Anderson, LLP. 1996 Report of Independent Public Accountants to the Executive Director of the Federal Retirement Thrift Investment Board. March 15.

Atkinson, Anthony B. 1987. "Income Maintenance and Social Insurance." In Auerbach, AJ. and M. Feldstein, eds. Handbook of Public Economics Vol. II. Elsevier Science Publishers B.V. (North-Holland).

Atkinson, Anthony B. 1989. Poverty and Social Security. New York: Harvester Wheatsheaf. Barr, Nicholas. 1992. "Economic Theory and the Welfare State: A Survey and Interpretation." Journal of Economic Literature 30 (June): 741-803.

Baumol, William J., Stephen M. Goldfeld, Lilli A Gordon, and Michael F. Koehn. 1990. The Economics of Mutual Fund Markets: Competition Versus Regulation. Rochester Studies in Economics and Policy Issues. New York: Kluwer Academic Publishers.

Borcherding, Thomas E., Werner W. Pommerehne, and Friedrich Schneider. 1982. "Comparing the Efficiency of Private and Public Production: The Evidence from Five Countries," Supplement 2 Journal of Economics.

Berger, Allen, J. David Cummins, and Mary Weiss. 1995 "The Coexistence of Multiple Line Systems for Financial Services: The Case of Property-Liability Insurance”. The Wharton School, Center for Research on Risk and Insurance Working Paper, March.

Caswell, Jerry. 1976. "Economic Efficiency in Pension Plan Administration: A Study of the Construction Industry". Journal of Risk and Insurance. June: 257-273.

Clark, Robert and Ann McDermed. 1990. The Choice of Pension Plans in a Changing Regulatory Environment. AEI Press: Washington, D.C.

Cummins, J. David and Mary A Weiss. 1995. "Measuring Cost Efficiency in the Property-Liability Insurance Industry". Journal of Banking and Finance 17:463-481. 
Diamond, Peter. 1994._"Privatization of Social Security: Lessons from Chile". Revista de Analysis Economico, 9 (1) June: 21-33.

Diamond, Peter and Salvador Valdés-Prieto. 1993. "Social Security Reforms," in Eds. B. Bosworth, R. Dornbusch, and R. Laban. The Chilean Economy: Policy Lessons and Challenges, Washington, D.C.: Brookings Institution.

Dickson, Joel. 1996. "Analysis of Financial Conditions Surrounding Individual Accounts", $\mathrm{R}^{39} \mathrm{eport}$ prepared for the 1994-5 Social Security Advisory Council. April.

Doggette, H. 1988. "Technological Change and Its Impact on the Management of Social Security Agencies", International Social Security Review. 4 (61): 355-367.

Elton, Edwin J., Martin Gruber, Sanjiv Das, and Matthew Hlavka. 1993. "Efficiency with Costly Information: A Reinterpretation of Evidence from Managed Portfolios". Review of Financial Studies v6 (1): 1-22.

Fidelity Investments, Prospectus, various dates. Boston, Mass: Fidelity.

Fields, J. and N. Murphy. 1989. "An Analysis of Efficiency in the Delivery of Financial Services:

The case of life insurance agencies" Journal of Financial Services Research (2): 323-356.

Friedman, Benjamin and Mark Warshawsky. 1990. "The Cost of Annuities: Implications for Saving Behavior and Bequests". Quarterly Journal of Economics 105 (1): 135-154.

Gardner, Linda and Martin Grace. 1993. "X-Efficiency in the US Life Insurance Industry". Journal of Banking and Finance: 17(2/3): 497-510.

Grace, Martin F and S. Timme. 1992. "An Examination of Cost Economies in the US Life Insurance Industry". Journal of Risk and Insurance 59: 72-103.

Greenwich Associates. 1995. Eleven Thorny Problems, Greenwich Report, Greenwich, CT [1995a]

Greenwich Associates. 1995. Higher Standards, Stretched Resources, Greenwich Report, Greenwich, CT [1995b]

Greenwich Associates. 1995. Investment Management 1995: Statistical Supplement, Greenwich Report, Greenwich, CT [1995c] 
Greenwich Associates. 1995. More Equities, Greater Diversification, Sensible Shifts, Greenwich Report, Greenwich, CT. [1995d]

Hay/Huggins Company, Inc. 1990. Pension Plan Cost Study. Report prepared for the PBCG, Washington, D.C., September.

Hoexter, Elsie. 1970. Administrative Expenses of Welfare and Pension Plans. US Department of Labor. Labor Management Services Administration. Washington, D.C.: USGPO.

Hsin, Ping-Lung and Olivia S. Mitchell. 1994. "The Political Economy of Public Pensions: Pension Funding, Governance, and Fiscal Stress". Revista de Analisis Economico. 9(1) June: 151168.

Hsin, Ping-Lung and Olivia S. Mitchell. Forthcoming. "Are Public Pension Plans Administratively Efficient?". In Positioning Pensions for the 21st Century. Eds. M. Gordon, O. S. Mitchell, M. Twinney. Pension Research Council. University of Penn. Press: Philadelphia.

Hustead, Edwin C. Forthcoming. "Retirement Income Plan Administrative Expenses: 1981 through 1996". In Mitchell, O. and S. Schieber, eds. Living with Defined Contribution Plans. Pension Research Council, The Wharton School Investment Company Institute (ICI). 1995. , 401(k) Plans: How Plan Sponsors See the Marketplace. ICI Research Report.

Investment Company Institute. 1995. Mutual Fund 1995 Fact Book. ICI: Washington, D.C. Ippolito, Richard A. 1989. “Efficiency with Costly Information: A Study of Mutual Fund Performance, 1965-1984". Quarterly Journal of Economics, February. 104(1): 1-23. James, Estelle and Robert Palacios. 1995. “The Cost of Administering Publicly-Mandated Pensions" Finance and Development 32(2), June.

Lakonishok, Joseph, Andrei Schleifer, and Robert Vishny. 1992. "The Structure and Performance of the Money Management Industry". Brookings Papers on Economic Activity: Microeconomics: 339-391.

Limbacher, Patricia. 1995. "ERISA Reform Hidden Agenda in 401(k) Furor". Pensions and Investments Dec. 1: 1. 
Mehay, Stephen, and Rodolfo Gonzalez. 1985 "Economic Incentives under Contract Supply of Local Government Services," Public Choice: 46.

Mesa-Lago, Carmelo. 1989. Ascent to Bankruptcy: Financing Social Security in Latin America. Pittsburgh, PA: University of Pittsburgh Press.

Mitchell, Olivia S. 1994. "Retirement Systems in the Developed and Developing World:

Institutional Structure, Economic Effects, and Lessons for Economies in Transition". Report prepared for the World Bank.

Mitchell, Olivia S. 1992. "Trends in Pension Benefit Formulas and Retirement Provisions". In Trends in Pensions 1992. Eds. J. Turner and D. Beller. Washington, D.C.: US Dept. of Labor, PWBA: 177-216.

Mitchell, Olivia S. and Emily Andrews. 1981. "Scale Economies in Private Multi-Employer Pension Systems", Industrial and Labor Relations Review, 34 (4) July 1981: 522-530.

Mitchell, Olivia S. and Gary Fields. 1994. "Designing Pensions for Developing Countries". Report to the ESP Division of the World Bank and Pension Research Council Working Paper, University of Pennsylvania.

Mitchell, Olivia S. and Ping Lung Hsin. Forthcoming. "Managing Public Sector Pensions". In Public Policy Toward Pensions. Eds. John. Shoven and Sylvester Schieber. Twentieth Century Fund.

Mitchell, Olivia S. and Ping-Lung Hsin. 1994. "Public Sector Pension Governance and Performance". NBER Working Paper 4632. January.

Mitchell, Olivia S. and Robert Smith. 1994. "Public Sector Pension Funding". Review of Economics and Statistics: $278-290$.

Mitchell, Olivia S. and Annika Sunden. 1993. An Examination of Social Security Administration Costs in the United States. Report to the Public Sector Management Division, LAC Technical Dept., The World Bank. 
Mitchell, Olivia S., Annika Sunden, and Ping-Lung Hsin. 1994. "Social Security Costs in Latin America, the Caribbean, and OECD Nations", Journal of International Compensation and Benefits, 2(4), Jan/Feb. [1994a]

Mitchell, Olivia S., Annika Sunden, Ping-Lung Hsin and Gary Reid. 1994. "An International Appraisal of Social Security Administration Costs". Report to the Public Sector Management

Division, LAC Technical Department of the World Bank. May. [1994b]

Mitchell, Olivia S. and Steven Zeldes. 1996. "A Framework for Analyzing Social Security Privatization". American Economic Review, March.

Myers, Robert J. 1992. "Can the Government Operate Programs Efficiently and Inexpensively?" Contingencies. March/April.

Myers, Robert J. 1992. "Chile's Social Security Reform After Ten Years," Benefits Quarterly, Third Quarter: 41-55.

Palacios, Robert. 1994,. "Determinants of Administrative Costs in Publicly Managed Pension Schemes". World Bank. Unpublished mimeo.

The Participant. 1996. "CREF Cuts Charges", May: 6.

Piñera, José. 1991. "Princípios y Fundamentos del Sistema Privado de Pensiones en Chile," In Análisis del Sistema Privado de Pensiones en Chile. Santiago, Chile: Congreso Iberoamericano, Asociación de Administradoras de Fondos de Pensiones.

Quinn, Joseph and Olivia S. Mitchell. 1996. "Prospects for Social Security Reform". American Prospect, May-June(26): 76-81.

Reid, Gary and Olivia S. Mitchell. 1995. Social Security Administration in Latin America and the Caribbean. Report to the Public Sector Modernization and Private Sector Development Unit, The World Bank, March.

Schieber, Sylvester and Gordon Goodfellow. Forthcoming. "Investment of Assets in Self Directed Retirement Plans". In Positioning Pensions for the 21st Century. Eds. M. Gordon, O.S. Mitchell, and M. Twinney. Pension Research Council: University of Pennsylvania Press, Philadelphia PA. 
Schutan, Bruce. 1995."Fidelity Pursuit Changing Face of Total Benefits Outsourcing". Employee Benefit News 9(5): 1, 18-19.

Social Security Administration (SSA). 1995. Social Security Bulletin, Annual Statistical Supplement, 1995. Washington, D.C.: USGPO.

Sunden, Annika and Olivia S. Mitchell. 1994. An Examination of Social Security Administration Costs in the United States. Report to the Public Sector Management Division, LAC Technical Department, World Bank, and Pension Research Council Working Paper, The Wharton School.

Technical Panel on Trends and Issues in Retirement Saving (TIRS). 1995. Final Report to the 199495 Advisory Council on Social Security, US Social Security Administration, September 1995. Turner, John and Daniel Beller, eds. Trends in Pensions, U.S. Department of Labor, Pension and Welfare Benefits Administration, Washington, DC: 1989.

US Department of Labor (USDOL), Pension and Welfare Benefits Administration. 1996. Abstract of Form 5500 Data Financial Reports, Bulletin \#5, Winter.

US General Accounting Office (USGAO). 1989. Poor Performers: How They Are Identified and Dealt With in the Social Security Administration, Washington, D.C.: USGPO, January. Valdés-Prieto, Salvador. 1993. "Administrative Costs in the Chilean Pension System: Evidence from an International Comparison," Instituto de Economía, Pontificia Universidad Catolica de Chile: Santiago, Chile, Mimeo, January.

Valdés-Prieto, Salvador. 1994. "Administrative Charges in Pensions in Chile, Malaysia, Zambia, and the United States,” Policy Research Working Paper No. 1372. World Bank: October.

Vanguard. 1995. Facts on Funds for your Retirement. Valley Forge, PA: Vanguard. December..

Vanguard. 1996. Plain Talk about Index Investing, Marketing Bulletin,.

Vanguard. Various years. Prospectus, various funds. Valley Forge, PA: Vanguard.

Vanguard. 1995. Ten Reasons to Index, Marketing Brochure.

Warshawsky, Mark. 1988. "Private Annuity Markets in the United States: 1919-1984", Journal of Risk and Insurance LV September: 518-28. 
Watanabe, Noriyasu. 1996. "Private Pension Plans in Japan". In Securing Employer-Provided Pensions: An International Perspective. Eds. Z. Bodie, O.S. Mitchell, and J. Turner. Pension Research Council, University of Pennsylvania Press: Philadelphia PA

Yuengert, Andrew M. 1993. "The Measurement of Efficiency in Life Insurance", Journal of Banking \& Finance: 17(2/3): 483-496.

World Bank. 1994. Averting the Old-Age Crisis: Policies to Protect the Old and Promote Growth. Policy Research Report, Policy Research Department, The World Bank: June.

$\mathrm{Zi}$, Hongmin. 1994. "Measurement of Cost Efficiency in the US Life Insurance Industry". Working Paper, Univ. of Pennsylvania, Wharton School.

${ }^{1}$ In the US, this topic was the subject of a recent (3/25/96) Senate Finance Committee hearing that reviewed options for privatization as described by members of the Social Security Advisory Council as well as the Chairs of the Technical Panels reporting to the Council. See also Quinn and Mitchell (1996).

2This section draws on Reid and Mitchell (1995) and Sunden and Mitchell (1994). It should be emphasized that the present paper focuses on the provision of retirement income, and not health care and welfare/social assistance. Also, disability benefits are treated only in passing. ${ }^{3} \mathrm{~A}$ discussion of the rationale for retirement systems is offered by Atkinson (1987 and 1989) and Barr (1992) among others.

4Private pension plans must also recognize a premium to cover the longevity, inflation, and interest rate risks they assume, whereas most government-run retirement systems will instead implicitly bear the costs and raise taxes if the need arises (c.f. Sunden and Mitchell, 1993; Mitchell et al. 1994; Reid and Mitchell 1995).

${ }^{5}$ Where possible, only old-age retirement programs were included in Table 1 but social security costs were not always broken down by type in developing countries.

${ }^{6}$ Here we do not investigate whether a social security program is consistent with national goals of growth and income distribution, though some systems are probably more conducive than others to these objectives (c.f. World Bank, 1994). 
?In the case of Argentina there was some question as to the proper cost to assess for payroll tax collections. The data given assume that average tax collections costs should be charged to the public pension system for collection of social security taxes; while this is probably too high a charge, no other figures are available (see Reid and Mitchell, 1995).

${ }^{8}$ High administrative expenses have also been experienced under Argentina's new private defined contribution system modeled after the Chilean regime; here, administrative charges currently amount to $32 \%$ of contributions (personal communication, Rafael Rofman). However the Argentine private pension system is only in its second year of operation, and charges would be expected to decline over time.

9It should also be noted that there are important difference in services rendered across systems in Chile; most private pension (AFP) members are not retired, while most public plan (INP) participants are retired.

${ }^{10}$ It should also be evident that system cost comparisons are sensitive to the measure of participants used. For instance, normalizing by beneficiaries yields US system cost estimates more than three and a half times higher than those generated by normalizing with contributors.

11 This high figure assumes that average rather than marginal tax collection costs should be assessed against the public plan. While this is no doubt unrealistic, more precise data do not exist. 12 Salvador Valdes-Prieto notes that the figures for Chile are not exactly comparable with those reported in other countries, since Chile's system exacts a one-time fee when the defined contribution monies are contributed, and no additional fees are charged on the accruing assets (personal communication). Larry Kotlikoff argues that it is more appropriate to spread the Chilean one-time up-front fee over the pension accrual phase in order to determine its impact on annualized returns which he estimates at approximately 80 basis points per year for younger contributors (personal communication).

${ }^{13}$ For the combined OASDI program, total administration costs amounted to $\$ 2,600 \mathrm{M}$ in 1994 , or $\$ 19$ per worker (and $\$ 14$ per participant). As a percentage of benefits paid, administrative costs for 
this segment of social security came to $0.93 \%$ of benefits, or $0.68 \%$ of contributions; and $0.63 \%$ or 63 basis points of the combined OASDI trust funds.

14 The fact that disability claims require collection of medical data and subsequent medical assessments probably helps explain why the process is more cumbersome.

${ }^{15}$ The data in the next three paragraphs are taken from Reid and Mitchell (1995).

${ }^{16}$ As might be expected, many developing countries national social security systems do not regularly provide data on the accuracy and timeliness of tax and benefit functions. This was true, for example, in a recent analysis of the Costa Rican national retirement system (Caja Costarricense de Seguridad Social, CCSS), the Argentine program (Administracion Nacional de la Seguridad Social, ANSeS), and the Chilean public retirement system (Instituto de Normalizacion Previsional, INP).

${ }^{17}$ Some would argue that the Chilean market's return should not be compared to those of developed countries since the Chilean AFP's were initially restricted to holding mainly government paper, and still are very heavily concentrated in Chilean firms. Hence their investment universe had very different risk/return characteristics than US or European markets.

${ }^{18}$ For examples of this literature see Borcherding et al. (1992) and Mehay and Gonzales (1985), among others.

${ }^{19}$ Benefits and system membership were too collinear to permit including both in the same equation.

${ }^{20}$ For example, a compilation of mutual fund returns and expenses appears weekly in the Wall Street Journal, and frequent updates are available from Lipper Analytical Services and Morningstar Mutual Fund Reports, among others.

21 The discussion in this paragraph draws on Vanguard (1995:2).

${ }^{22}$ Between 1981 and 1994, the expense ratio for the lowest-cost family of mutual funds fell $48 \%$, from $0.58 \%$ to $0.30 \%$, though for the mutual fund industry as a whole expense ratios rose $42 \%$, from $0.65 \%$ to $0.92 \%$ of assets (Vanguard $1995: 3$ ). 
${ }^{23}$ Mutual funds as a whole averaged yearly portfolio turnover rates of $76 \%$, much higher than the $2-6 \%$ rates for some of the prominent funds such as Fidelity's Market Index, Vanguard's Total Stock Portfolio, and Vanguard's 500 Portfolio (Vanguard, 1996:2, see also Table 8).

24 The Ippolito data were reanalyzed by Elton et al (1993) who conclude that mutual funds did not earn higher than average returns. Analysis by Lakonishok et al. (1992) suggests that average mutual fund performance lagged behind index fund performance by $7-80$ basis points over the Ippolito study period (1964-85), but detects evidence of better mutual fund performance over the period 1983-89.

25Vanguard prospectus April 23, 1996; personal communication with Joel Dickson, May 1996. ${ }^{26}$ Within the last year Fidelity Investments announced that it would be the first mutual fund group to provide a full menu of benefit offerings for companies considering benefits outsourcing (cf Shutan 1995).

${ }^{27}$ Under ERISA, small plans do not face the same annual reporting requirements.

${ }^{28}$ Because the market for pension professionals was assumed to be national in scope, the lack of cross-sectional data on input prices was not deemed critical.

${ }^{29}$ The range of recordkeeping costs for $401(\mathrm{k})$ plans suggested by industry experts is $\$ 15-30$ per year.

${ }^{30}$ What is interesting is that in the 401(k) plan containing only an index fund, adding the annuity costs increases costs by 32 basis points, while the annuity raises costs by only $3-8$ basis points for the money market, balanced, and equity accounts. This may be explained by the fact that few mutual funds offer an annuity product in the large institutional 403(b) marketplace, so that reported data may be skewed by an overweighting of smaller retail plans. Hence adding the annuity charge appears to raises expense ratios by a low of $4 \%$ to a high of double, depending on the fund. ${ }^{31}$ In the last few years, however, a handful of states and municipalities have offered a defined contribution alternative. For example the city of Westminster, Colorado provides defined contribution plans for its police, firefighters, and general city employees, holding plan assets or $\$ 43 \mathrm{M}$ for some 770 participants. Expenses per participant are reported at $\$ 248$ per year per person 
(\$1994). On a percentage basis, annual expenses total $0.45 \%$ of assets, or $5.4 \%$ of contributions.

These expenses are allocated roughly two-fifths to operational expenses, and three-fifths to money management costs.

${ }^{32}$ These public plan costs could still be understated, to the extent that public sector pensions probably do not fully account for collection costs, the use of public land and buildings, and benefits provided by other government agencies.

${ }^{33}$ In related work, Mitchell and Hsin (1994) and Mitchell and Smith (1994) found that public plan funding and investment performance was related to the composition and responsibilities of the Pension Boards managing the plans. Specifically, funding and returns were lower when a pension plan had more participants on the Board, when in-state investments were required, and when Board members were not required to carry liability insurance.

${ }^{34}$ For studies on life insurance industry costs and efficiency see Grace and Timme (1992); Fields and Murphy (1989); Gardner and Grace (1993); Yuengert (1993), Zi (1994).

${ }^{36}$ Testimony of Sylvester Schieber, Senate Finance Committee, March 25, 1996.

${ }^{36}$ For further discussion of the Chilean system see Diamond and Valdes Prieto (1994) and World Bank (1994).

37There is debate over whether this plan would be mandatory or optional, and how funds would be collected. If contributions were collected at the individual level instead of continuing to use the Internal Revenue Service, collection costs could also be expected to rise substantially. Many of the issues raised in this discussion are taken up by the TIRS Technical Panel Report (1995).

${ }^{38}$ This is one aspect of the current Social Security retirement account that might continue to be managed by the government, though encouraging the formation of groups for insurance purposes may suffice. 
Table 1. Administrative Costs as a Percentage

\section{of Social Security Benefit Expenditures}

L. Amer./Carribbean

Mean

Standard deviation

Argentina

Bahamas

Barbados

Belize

Bolivia

Brazil

Chile

Colombia

Costa Rica

Dominica

Dominican Republic

Ecuador

El Salvador

Grenada

Guatemala

Guyana

Honduras

Jamaica

Mexico

Panama

Peru

St. Lucia

Trinidad and Tobago

Uruguay

Venezuela
27.78

31.16

2.30

30.75

5.56

89.49

21.39

7.00

8.00

81.80

4.75

46.97

31.72

13.55

33.40

9.85

12.72

22.66

18.25

6.40

23.55

5.88

130.98

48.31

15.29

6.51

17.46
OECD

Mean

Std. dev.

3.12

1.28

Australia $\quad 1.22$

Austria $\quad 2.48$

Belgium $\quad 4.55$

Canada $\quad 2.80$

Denmark $\quad 2.98$

Finland $\quad 3.36$

France $\quad 4.18$

Germany $\quad 2.86$

Greece $\quad 6.72$

Iceland $\quad 1.71$

Ireland $\quad 4.88$

Italy $\quad 2.20$

Japan $\quad 1.79$

Luxembourg $\quad 2.74$

Netherlands $\quad 3.10$

New Zealand $\quad 2.42$

Norway $\quad 1.00$

Portugal $\quad 4.86$

Spain $\quad 2.81$

Sweden $\quad 4.24$

Switzerland $\quad 3.04$

Turkey $\quad 2.62$

United Kingdom $\quad 3.10$

United States $\quad 3.28$ 


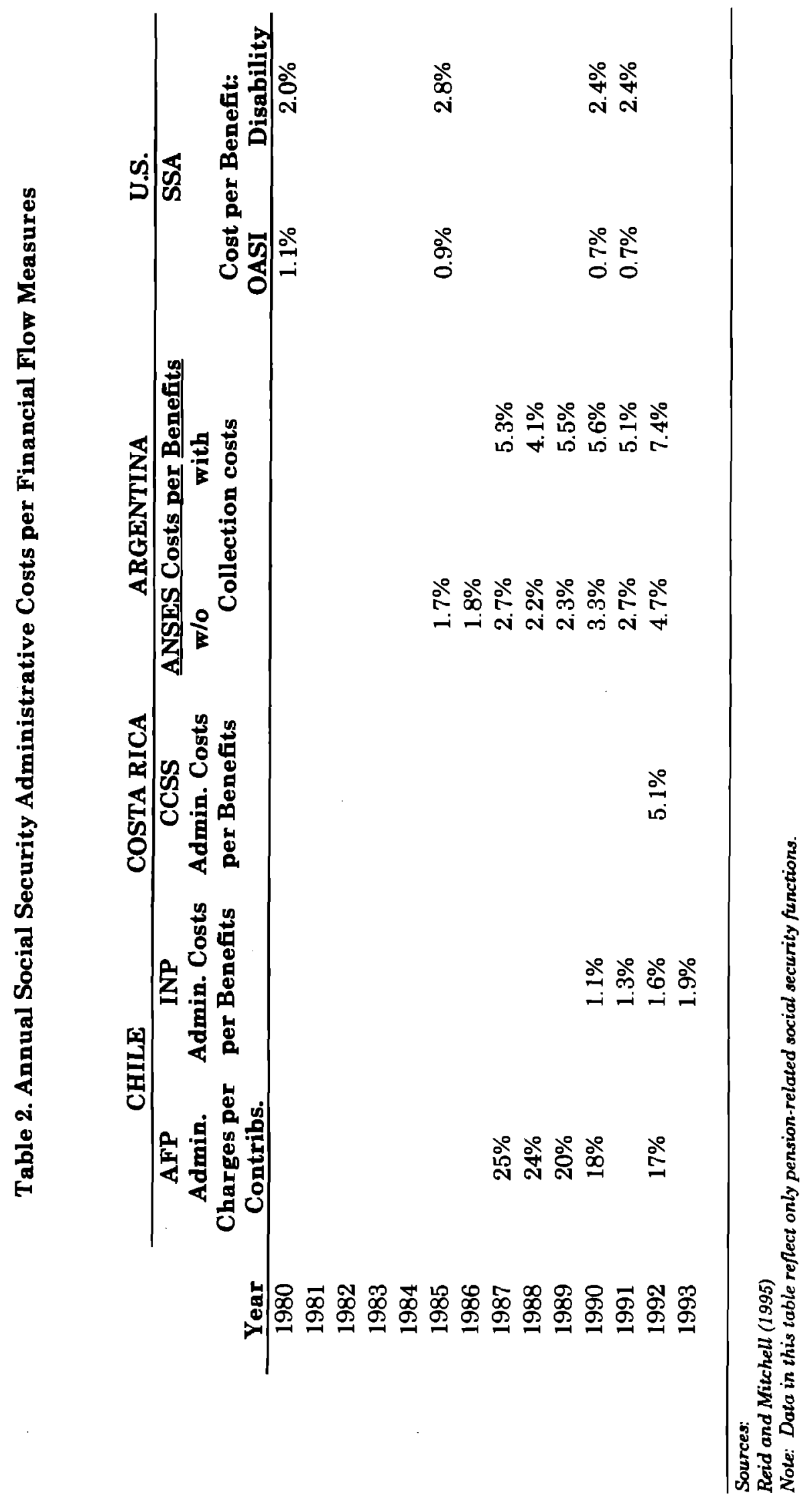




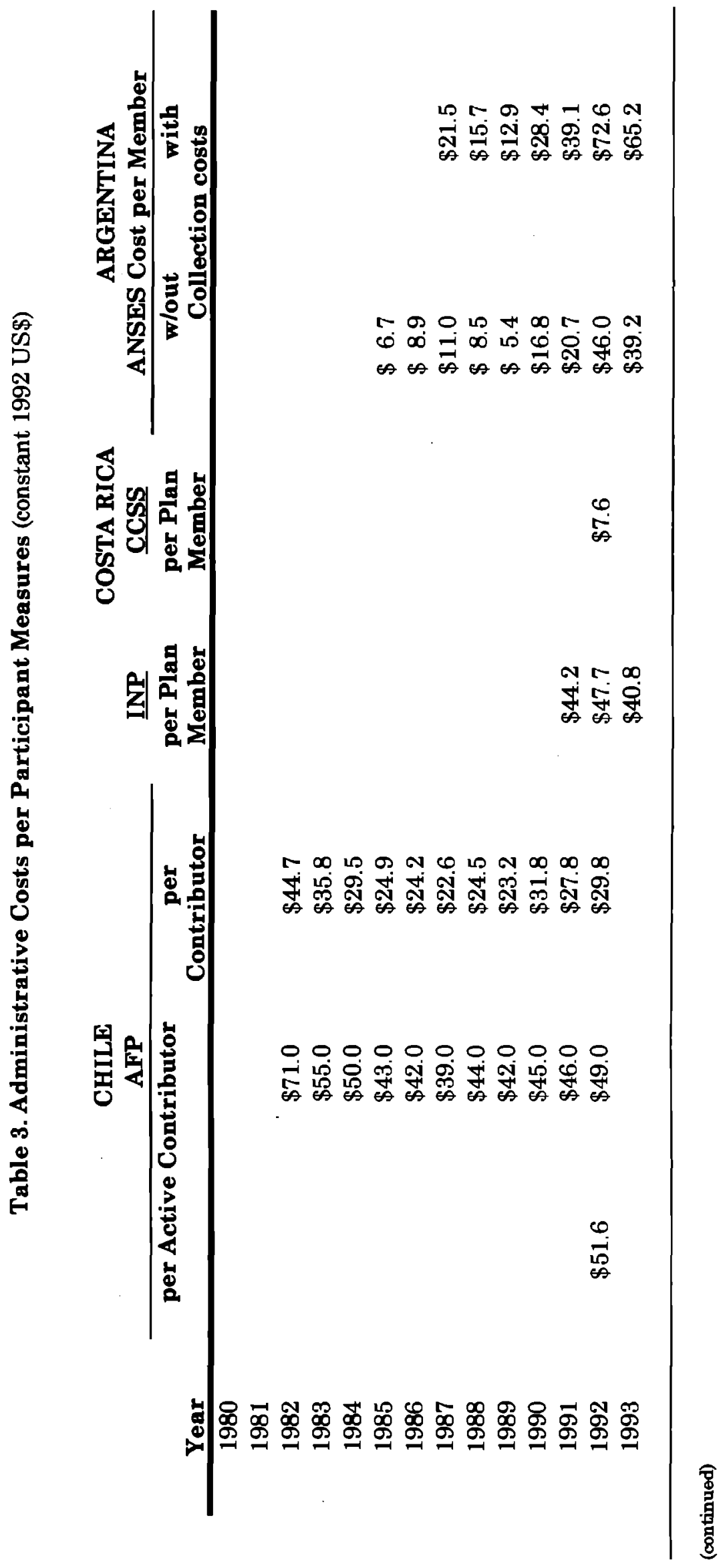




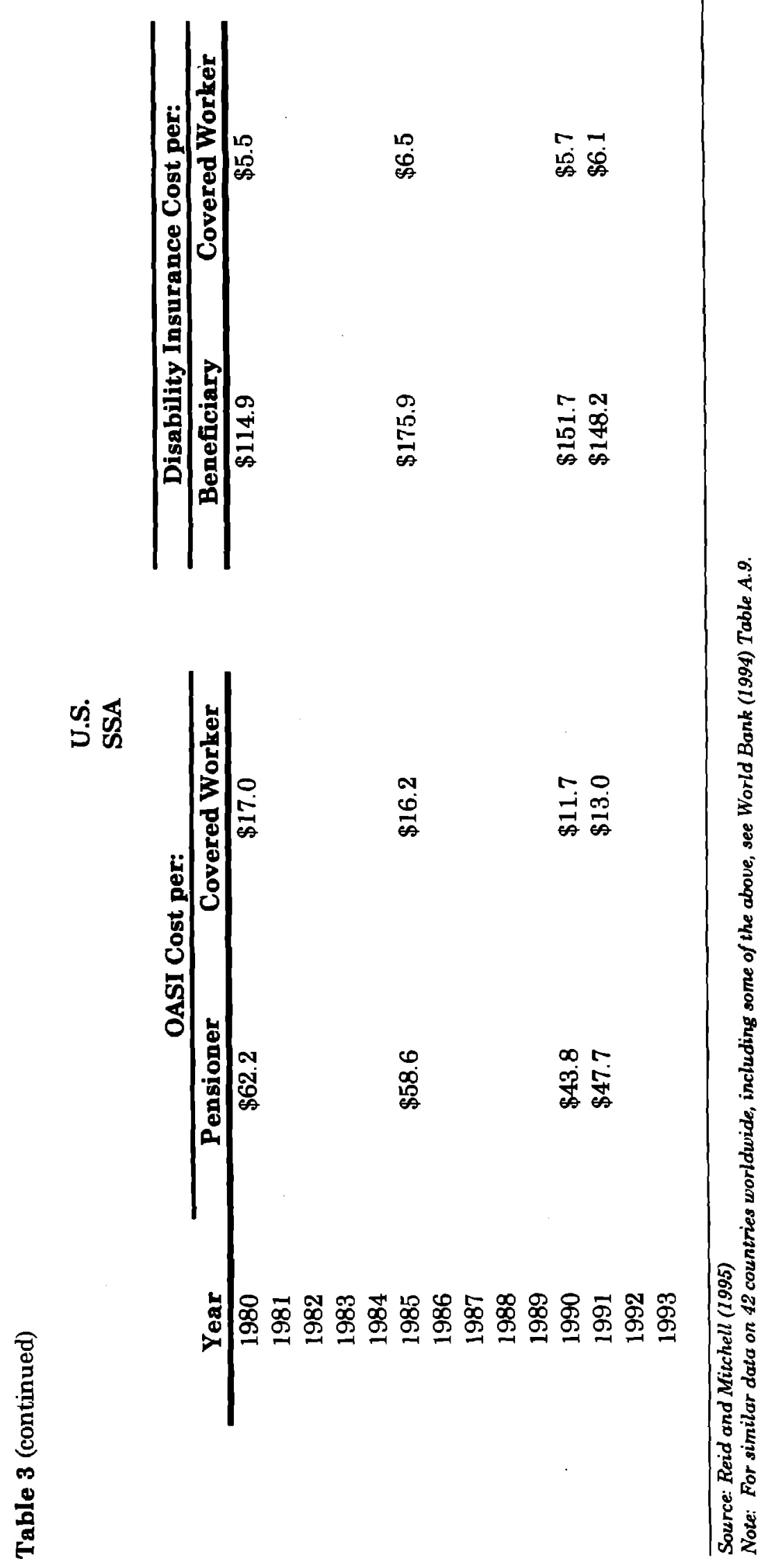


Table 4. Facts and Figures about OASDI (\$1994)

Revenues and Tax Base

OASI Revenues (\$M)

DI Revenues (\$M)

Workers with Taxable Earnings (M)

Workers Fully Insured (M)

Covered Earnings (\$M)

Av. Earnings/Cov. Worker (\$)

OASI Revenues/Covered Worker (\$)

OASI Revenues/Cov. Earnings (\%)

OASDI Revenues/Cov. Worker (\$)

OASDI Revenues/Cov. Earnings (\%)

$\begin{array}{rr}\begin{array}{c}\text { Quantity } \\ \$ 328,271\end{array} & \text { Source: } \\ \$ 52,841 & \mathrm{~T} 4 . \mathrm{A} 1 \\ 139 & \mathrm{~T} 4 . \mathrm{A} 2 \\ 173 & \mathrm{~T} 4 . \mathrm{B} 1 \\ \$ 3,229,100 & \mathrm{~T} 4 . \mathrm{Cl} \\ \$ 23,231 & \mathrm{~T} 4 . \mathrm{B} 1 \\ \$ 2,362 & \text { [au.calc] } \\ 10 \% & \text { [au.calc.] } \\ \$ 2,742 & \text { [au.calc] } \\ 12 \% & \text { [au.calc.] } \\ & \text { [au.calc] }\end{array}$

\section{Beneficiaries and Benefits}

OASI Benefits Paid (\$M)

$\$ 279,068$

$\$ 37,704$

37

OASI Recipients (M)

DI Recipients (M)

Av. Annual Ret.Wkr. Benefit (\$)

Av. Ret. Wkr. Ben/Av. Cov. Earnings (\%)

Av. Disabled Wkr. Benefit (\$)

Covered workers + OASDI Recip's

\section{Trust Fund Accumulation}

OASI Fund yr end ' $94(\$ M)$

DI Fund yr end '94 (\$M)

OASI Fund/Revenues (\%)

OASDI Fund/Revenues (\%)

OASDI Funds/Part's (\$)
$\$ 413,460$

$\$ 22,925$

$126 \%$

$115 \%$

$\$ 2,399$

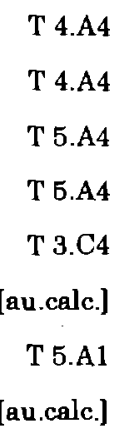

T 4.A1

T 4.A2

[au.calc.]

[au.calc.] [au.calc.] 
(continued)

Annual OASDI Administrative Costs

Administrative Costs (\$M)

$\$ 2,600$

p. 14

Admin.Costs/Cov. Worker (\$)

$\$ 19$

Admin.Costs/Participant (\$)

$\$ 14$

Admin.Costs/Bens Paid (\%)

$0.93 \%$

Admin.Costs/Trust Fund (\%)

$0.63 \%$

Admin.Costs/Contrib's (\%)

$0.68 \%$

[au calc.]

[au.calc.; act. + ret.]

[au.calc.]

[au.calc.]

[au.calc.]

Annual OASI Administrative Costs

Administrative Costs (\$M)

$\$ 1,600$

p. 14

Admin.Costs/Cov. Worker (\$)

$\$ 12$

Admin.Costs/Participant (\$)

$\$ 9$

[au.calc.]

Admin.Costs/Bens Paid (\%)

$0.57 \%$

[au.calc.; act. + ret.]

Admin.Costs/Trust Fund (\%)

$0.39 \%$

[au.calc]

Admin.Costs/Contrib's (\%)

$0.42 \%$

[au.calc.]

[au.calc]

Administrative Data ( All OASDHI included in counts)

No. of SSA employees

64,234

T 2.F2

No. of SSA offices

Field \& Regional offices

1,412

T 2.F1

Appeals/Hearings offices

146

T 2.F1

Service Centers

6

T 2.F1

Data Operations Center

1

T 2.F1

Claims Information

Processed Claims/yr (000)

3,206

T $2 . F 4$

Accuracy Rates - OASI (\$)

$99.80 \%$

T 2.F7

Source: Social Security Administration, 1995 Annual Statistical Supplement,

USGPO: 1995; refo, given in last column. 
Table 5. US Social Security Administration Costs Over Time (Per Capita, \$1994)

$\begin{array}{lcc}\text { Program } & \begin{array}{c}\text { Admin. Cost Per } \\ \text { Beneficiary }\end{array} & \begin{array}{c}\text { Admin. Cost Per } \\ \text { Covered Worker }\end{array}\end{array}$

Old Age \& Survivor Insurance

$\begin{array}{rrr}1980 & \$ 65.72 & \$ 35.95 \\ 1985 & 61.91 & 17.13 \\ 1990 & 46.25 & 12.35 \\ 1994 & 44.10 & 11.83\end{array}$

Disability Insurance

$\begin{array}{rrr}1980 & \$ 121.43 & \$ 5.77 \\ 1985 & 185.85 & 6.86 \\ 1990 & 160.28 & 5.98 \\ 1994 & 259.19 & 7.40\end{array}$

\section{Hospital Insurance}

$\begin{array}{rrr}1980 & \$ 136.34 & \$ 8.16 \\ 1985 & 165.39 & 9.25 \\ 1990 & 129.59 & 6.20 \\ 1994 & 164.03 & 9.09\end{array}$

Supplementary Medical Insurance

$\begin{array}{rrr}1980 & \$ 61.59 & \$ 9.68 \\ 1985 & 58.00 & 10.45 \\ 1990 & 63.55 & 12.95 \\ 1994 & 57.56 & 12.22\end{array}$

Source: 1980-90 figures from Sunden and Mitchell (1993).

1994 data from Social Security Annual Statistical Supplement,

T. $4 A I$ and $2,4 B I, 5 A 4,8 B I$ and 2 


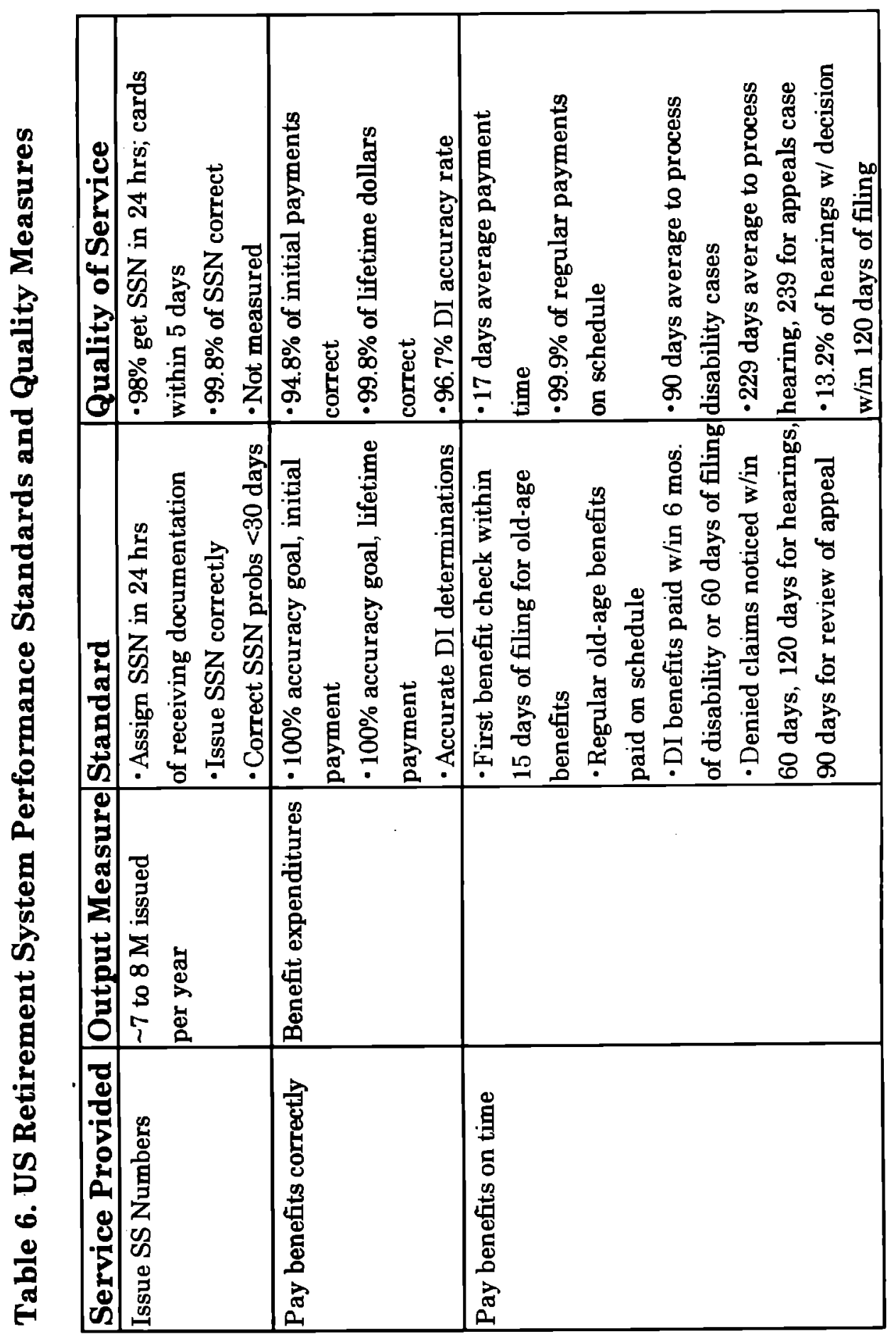




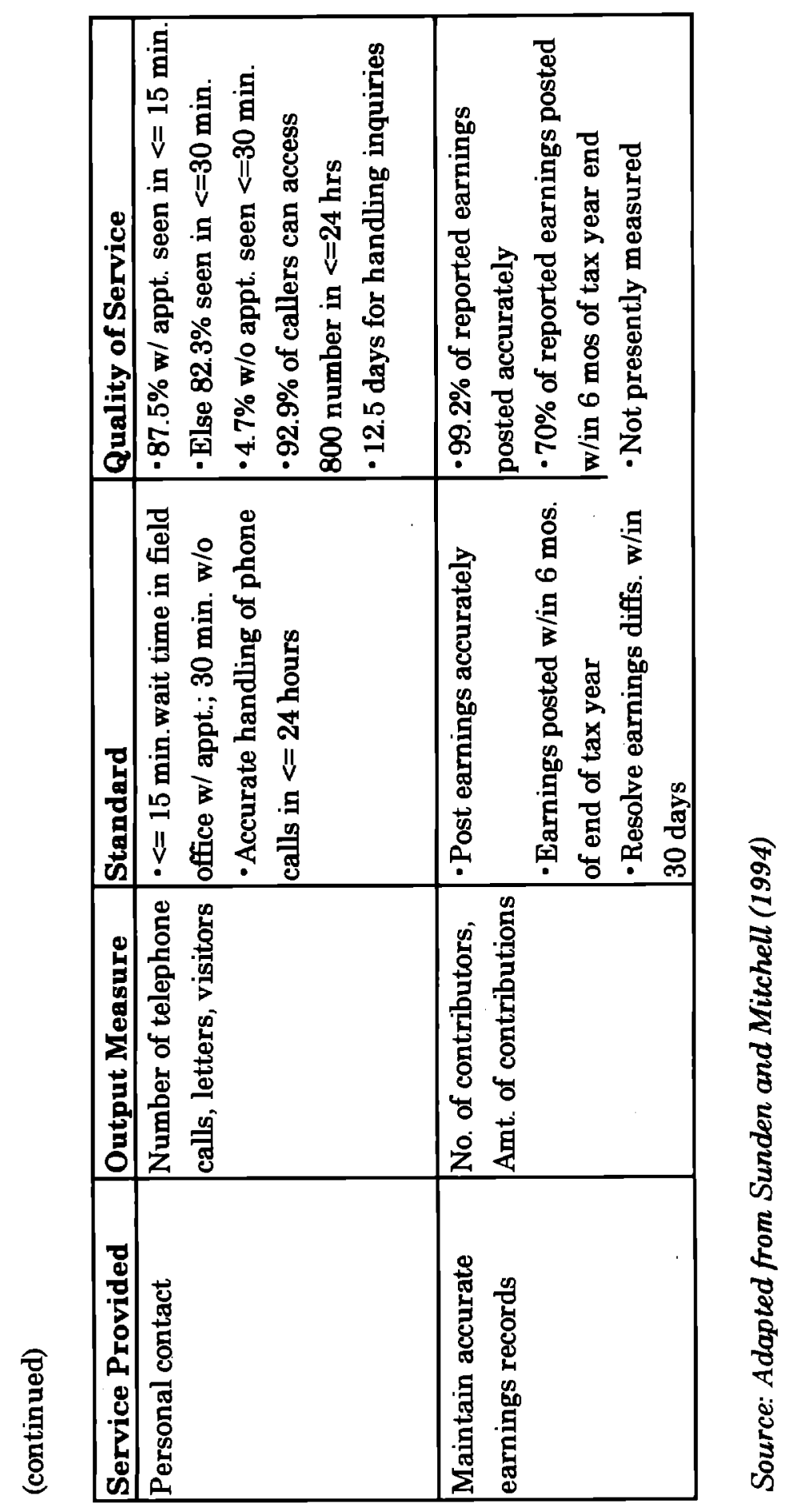




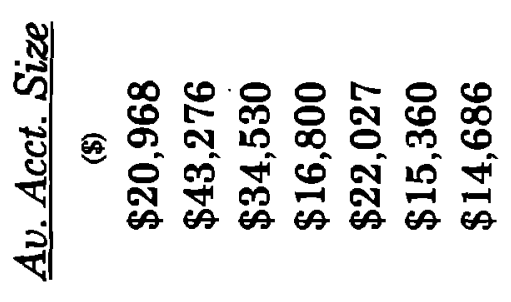

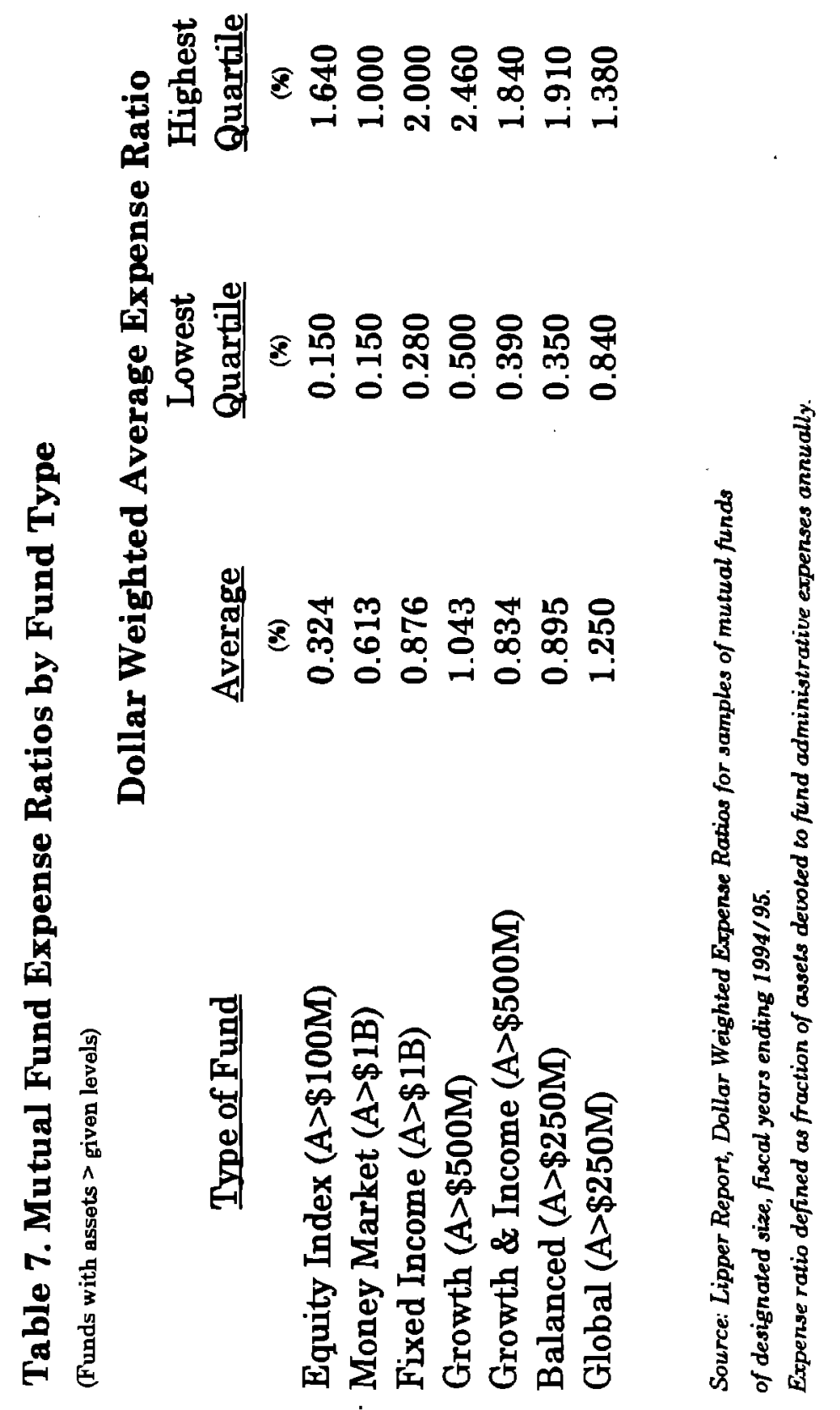


Table 8. Large Mutual Fund Portfolio Expense Ratios and Other Data

\begin{tabular}{lccc}
\hline & $\begin{array}{c}\text { Exp. Ratio } \\
\text { (\% of assets) }\end{array}$ & $\begin{array}{c}\text { Size of Fund } \\
(\$ \mathrm{M})\end{array}$ & $\begin{array}{c}\text { Turnover Rate } \\
(\%)\end{array}$ \\
\hline $\begin{array}{l}\text { Fidelity Funds } \\
\begin{array}{l}\text { Market Index } \\
\text { (S\&P index) }\end{array}\end{array}$ & $0.45 \%$ & $\$ 288$ & $2 \%$ \\
$\begin{array}{l}\text { Blue Chip } \\
\text { (blue chip stock fund) }\end{array}$ & 1.02 & 2,229 & 182 \\
$\begin{array}{l}\text { Fidelity Fund } \\
\text { (LT capital growth) }\end{array}$ & 0.64 & 1,592 & 157 \\
$\begin{array}{l}\text { Disciplined Equity } \\
\text { (undervalued S\&P) }\end{array}$ & 0.96 & 2,088 & 221 \\
$\begin{array}{l}\text { Contrarian } \\
\text { (undervalued stock) }\end{array}$ & 1.00 & 8,694 & 235 \\
\hline
\end{tabular}

\section{Vanguard Funds}

Total Stock Portfolio

$0.25 \% \mathrm{~g}$

$\$ 786^{\mathrm{h}}$

$2 \%^{\mathrm{i}}$

(Wilshire 5000 index)

500 Portfolio

$0.20^{j}$

$9,356^{k}$

$6^{1}$

(S\&P index)

Value Portfolio

$0.20 \mathrm{~m}$

$297 \mathrm{n}$

32 。

(large-cap index)

Balanced Index

$0.20^{\mathrm{p}}$

403 q

$16^{\mathrm{r}}$

(60/40 stocks/bonds)

Total Bond Portfolio

$0.20^{\mathrm{s}}$

$1,731^{\mathrm{t}}$

$33^{4}$

- Fidelity Market Index Fund prospectus6/95. Also an additional $\$ 10$ account fee charged per account per year and a .50\% redemption fee is charged on shares held less than 180 days. Redemption fee not included in returns figure given.

b Assumes annual account larger than $\$ 2,500$; else $\$ 12$ annual account maintenance fee charged. Total returns do not include one-time sales charge.

c Fidelity Blue Chip Grow th Fund Prospectus, 11/95.

d Fidelity Fund prospectus, 8/95. Also see note a.

- Fidelity Disciplined Equity Fund prospectus, 12/95. Also see note a.

I Fidelity Contrarian Fund prospectus, 2/95.

- Vanguard Facts on Funds, 12/95. Includes $\$ 10$ annual account maintenance fee charged to account smaller than $\$ 10,000$.

b 1994 year end; Vanguard Index Trust Prospectus, Rev. 9.95.

i 1994 year end; Vanguard Index Trust Prospectus, Rev. 9.95.

i Vanguard Facts on Funds, 12/95. Includes $\$ 10$ annual account maintenance fee charged to account smaller than $\$ 10,000$. Also portfolio transaction fee of $0.25 \%$ per dollar invested assessed in 1995 (not included in expense ratio).

1994 year end; Vanguard Index Trust Prospectus, Rev. 9.95.

I 1994 year end; Vanguard Index Trust Prospectus, Rev. 9.95.

m Vanguard Facts on Funds, 12/95. Includes $\$ 10$ annual account maintenance fee charged to account smaller than $\$ 10,000$.

- 1994 year end; Vanguard Index Trust Prospectus, Rev. 9.95.

- 1994 year end; Vanguard Index Trust Prospectus, Rev. 9.95.

p Vanguard Facts on Funds, 12/95. Includes $\$ 10$ annual account maintenance fee charged to account smaller than $\$ 10,000$.

q 1994 year end; Vanguard Balanced Index Fund Prospectus, Rev. 4.95

r 1994 year end; Vanguard Balanced Index Fund Prospectus, Rev, 4.95.

- Vanguard Facts on Funds, 12/95. Includes $\$ 10$ annual account maintenance fee charged to account smaller than $\$ 10,000$.

' 1994 year end; Vanguard Bond Index Fund Prospectus, Rev. 9.95.

u 1994 year end; Vanguard Bond Index Fund Prospectus, Rev. 9.95. 


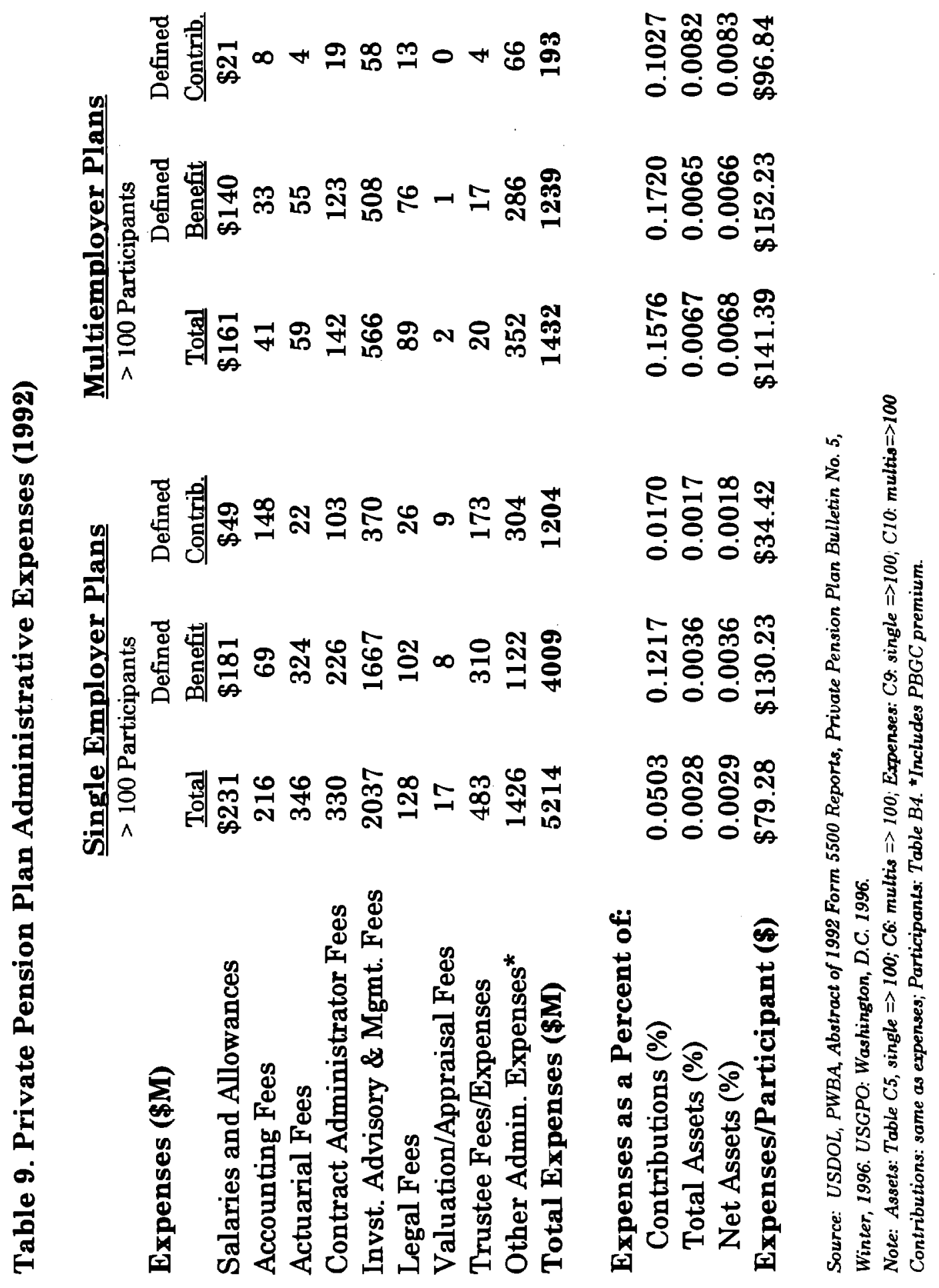


Table 10. Expenses for 401(k) Plans Holding Mutual Funds

Short Bonds

Intermed. Bonds

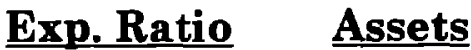

Long Bonds

Balanced/Total Return

(\%)

$(\$ B)$

0.84

$\$ 46$

1.01

$\$ 131$

1.16

$\$ 71$

Income/Utility

1.41

$\$ 132$

Growth/income

1.36

$\$ 99$

Long Term Growth

1.27

$\$ 290$

Agressive Growth

1.44

$\$ 340$

Global Bonds

1.58

$\$ 136$

Int'//Global Equity

1.54

$\$ 39$

1.88

$\$ 175$

Source: Plan Sponsor, Feb. 1996, p. 75 


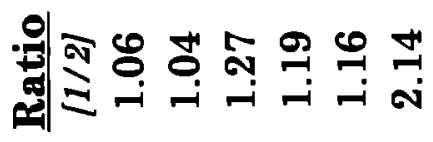

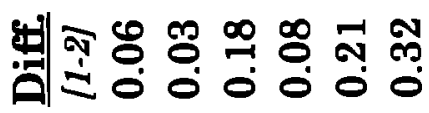

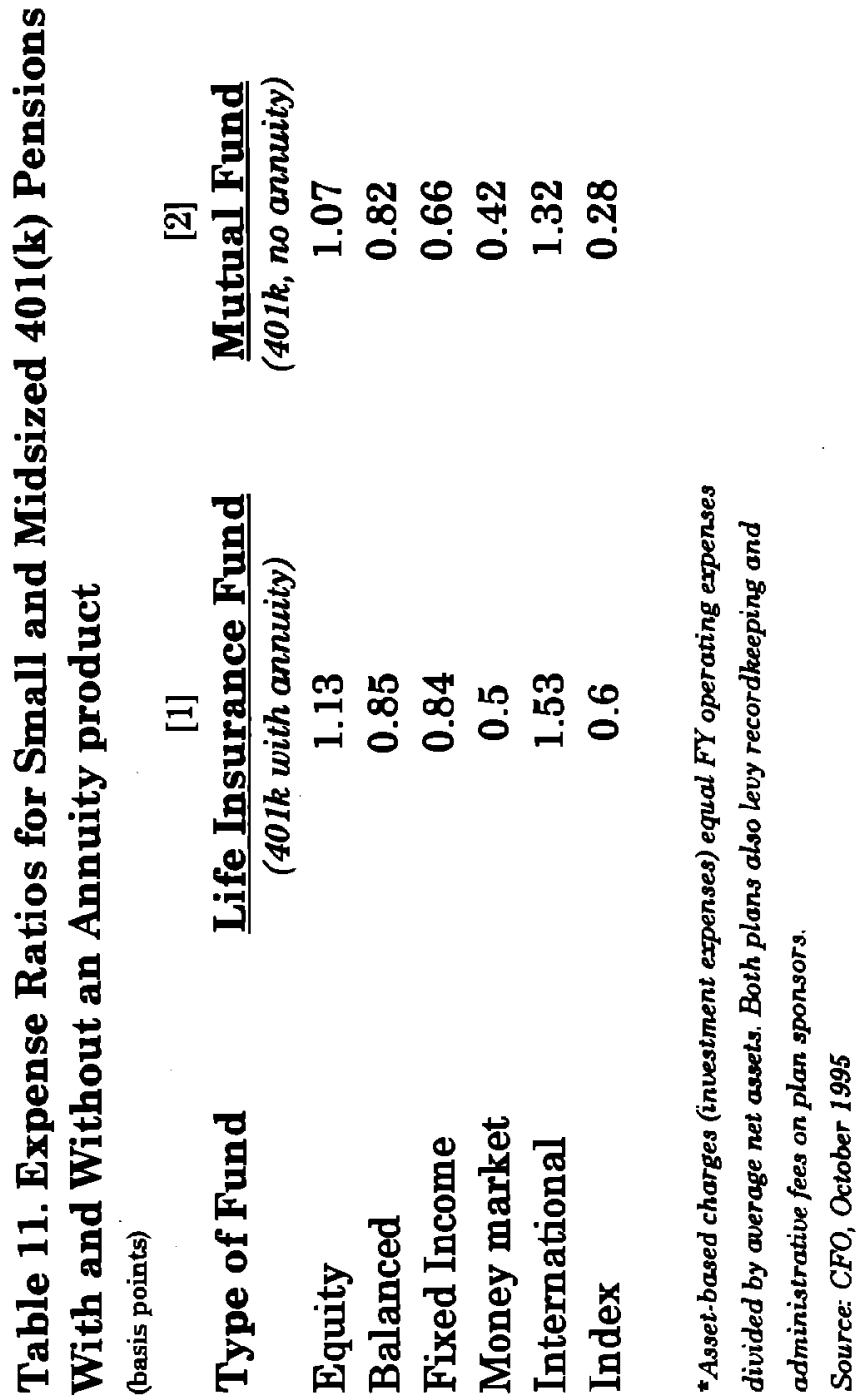




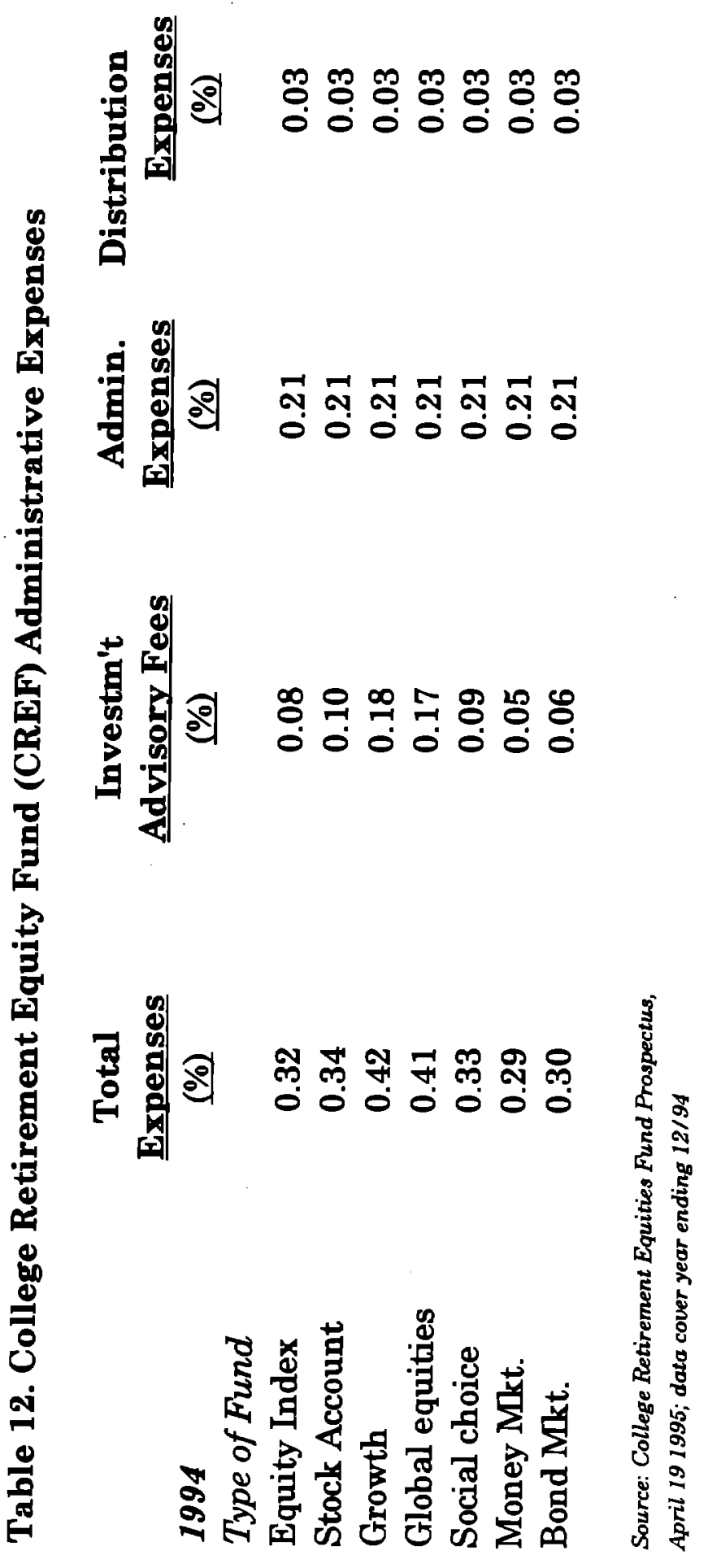


Table 13. Federal Retirement Thrift Investment Board Financial Data (1995\$)

I. Summary Data, Federal Thrift Plan (year end 1995)

Average Account Size

Total Participants

Investments

Total Investments

Net Assets

Contributions

Participant

Employer

Administrative Expenses

As $\%$ of net assets

As \% of total contributions

Investment Expenses

As $\%$ of net assets

As \% of total contributions

II. Data by Fund Type

US Govt. Securities Investment Fund

Assets

Admin. Expenses

Admin. Expenses/Assets

Wells Fargo Equity Index Fund

Assets

Admin. Expenses

Admin. Expenses/Assets

Wells Fargo US Debt Index Fund

Assets

Admin. Expenses

Admin. Expenses/Assets
$2.2 \mathrm{M}$

$\$ 26.5 \mathrm{~B}$

$36.3 \mathrm{~B}$

$\$ 5.6 \mathrm{~B}$

$\$ 3.8 \mathrm{~B}$

$\$ 1.8 \mathrm{~B}$

$\$ 33.4 \mathrm{~B}$

$0.09 \%$

$0.59 \%$

$\$ 0.002 B$

$0.006 \%$

$\mathbf{0 . 0 3 \%}$

$\$ 12.8 \mathrm{~B}$

\$0.024B

$0.19 \%$

\$11.5B

$\$ 0.008 \mathrm{~B}$

$\mathbf{0 . 0 7 \%}$

\$2.2B

$\$ 0.002 \mathrm{~B}$

$0.09 \%$

Note: Expenses associated with collection of payroll contributions not included in expense figures. Fiduciary insurance premiums set at zero in 1995. Investment expense ratio not available on a per.fund basis.

Source: Arthur Andersen LLP (1996). 
Table 14. Actuarial Analysis of Defined Benefit Pension Administrative Costs Per Person (\$1994)

\begin{tabular}{lccccccc}
\hline & \multicolumn{7}{c}{ Size of Pension Plan } \\
Year & \multicolumn{15}{c}{ 15 Participants in Plan } & \multicolumn{1}{c}{ 10,000 Participants in Plan } \\
\cline { 2 - 7 } & DB & DC & DC/DB & DB & DC & DC/DB \\
\hline 1981 & $\$ 184$ & 131 & $71 \%$ & $\$ 22$ & 24 & $110 \%$ \\
1985 & 456 & 374 & 82 & 31 & 32 & 104 \\
1991 & 518 & 259 & 74 & 62 & 46 & 74 \\
\hline
\end{tabular}

Source: Author's calculations from Hay/Huggins (1990), p. 31, 39 
Table 15: Defined Contribution Asset Holdings by Participant Age

Age of Plan Participant

\begin{tabular}{|c|c|c|c|c|c|}
\hline Proportion of Assets Held In: & $21-30$ & 31.40 & $41 \cdot 50$ & $51-60$ & $61+$ \\
\hline Fixed-Income Funds & $41 \%$ & $43 \%$ & $49 \%$ & $62 \%$ & $85 \%$ \\
\hline Domestic Equity Funds & 39 & 36 & 30 & 22 & 10 \\
\hline Balanced Funds & 6 & 8 & 11 & 8 & 1 \\
\hline Company Stock Funds & 11 & 9 & 6 & 6 & 3 \\
\hline International Equity Funds & 3 & 3. & 4 & 3 & 1 \\
\hline
\end{tabular}

Source: Derived from Schieber and Goodfellow (forthcoming), Table 4. Note: Columns may not sum to 100 percent due to rounding error. 